\title{
Mitochondria-targeted oxygen probes based on cationic iridium complexes with a 5-amino-1, 10-phenanthroline ligand
}

Toshitada Yoshihara, ${ }^{\mathrm{a}}$ Saori Murayama, ${ }^{\mathrm{a}}$ Tsuyoshi Masuda, ${ }^{\mathrm{a}}$ Toshiki Kikuchi, ${ }^{\mathrm{a}}$ Kohei Yoshida,

${ }^{a}$ Masahiro Hosaka ${ }^{b}$ and Seiji Tobita ${ }^{a *}$

${ }^{a}$ Department of Chemistry and Chemical Biology, Gunma University, Kiryu, Gunma 376-8515, Japan

${ }^{\mathrm{b}}$ Department of Biotechnology, Akita Prefectural University, Shimoshinjo, Akita 010-0195, Japan

* Corresponding author

Seiji Tobita

Department of Chemistry and Chemical Biology, Gunma University

1-5-1 Tenjin-cho, Kiryu, Gunma 376-8515, Japan

TEL +81-277-30-1210

FAX +81-277-30-1213

e-mail address: tobita@gunma-u.ac.jp

Keywords

Iridium complex, phosphorescence, mitochondria, oxygen probes, living cells 


\section{Abstract}

A cationic iridium(III) complex (btp) $\operatorname{Ir}\left(\right.$ phen- $\left.\mathrm{NH}_{2}\right)\left(\mathrm{btp}=\right.$ benzothienylpyridine; phen- $\mathrm{NH}_{2}=$ 5-amino-1,10-phenanthroline) and its analogues with extended $\pi$-electronic structures $(\mathrm{btq})_{2} \operatorname{Ir}\left(\right.$ phen- $\left.\mathrm{NH}_{2}\right) \quad(\mathrm{btq}=$ benzothienylquinoline $), \quad(\mathrm{ttph})_{2} \operatorname{Ir}\left(\mathrm{phen}-\mathrm{NH}_{2}\right) \quad(\mathrm{ttph}=$ thienothiophenylphenanthridine), (btph) $)_{2} \operatorname{Ir}\left(\right.$ phen- $\left.\mathrm{NH}_{2}\right)$ (btph = benzothienylphenanthridine $)$ have been designed and synthesized to develop new oxygen probes for living cells. The photophysical and cellular properties of these complexes were systematically investigated by using (btp) $)_{2} \operatorname{Ir}(\mathrm{acac})$ and its derivatives as reference compounds. The extension of the $\pi$-electronic systems of ligands resulted in remarkable red shifts in the absorption and phosphorescence spectra; the phosphorescence bands of $(\operatorname{ttph})_{2} \operatorname{Ir}\left(\right.$ phen- $\left.\mathrm{NH}_{2}\right)$ and (btph) $)_{2} \operatorname{Ir}\left(\right.$ phen- $\left.\mathrm{NH}_{2}\right)$ appeared in the near-infrared region, maintaining the relatively high phosphorescence quantum yields $\left(\Phi_{\mathrm{p}}^{0}=0.14-0.24\right)$. Dimethylation and diethylation of the amino group of the phen- $\mathrm{NH}_{2}$ ligand in $(\mathrm{btp})_{2} \operatorname{Ir}\left(\mathrm{phen}-\mathrm{NH}_{2}\right)$ and its analogues significantly enhanced the cellular uptake efficiency as compared with their neutral analogues with an acetylacetonate (acac) ligand. The cationic iridium(III) complex (btp) $)_{2} \operatorname{Ir}\left(\mathrm{phen}-\mathrm{NH}_{2}\right)$ and its analogues internalized into living HeLa cells showed selective distribution into mitochondria. Owing to the high cellular uptake, relatively high cytotoxicity was found for the cationic iridium complexes. The phosphorescence intensity of newly developed iridium complexes exhibited oxygen response in HeLa cells, demonstrating that these complexes have potential as mitochondria-selective oxygen sensors for biological cells and tissues. 


\section{Introduction}

Iridium(III) complexes have received considerable attention as phosphorescent materials for organic light-emitting diodes (OLED) [1,2], because phosphorescent OLED allows for harvesting of both triplet and singlet excitons. Various iridium complexes have been synthesized for this purpose. Recently, extensive studies on iridium complexes opened up new possibilities as biological luminescent probes [3-9], because they offer a variety of advantages as biological probes, including high luminescence efficiencies, large Stokes shifts that can minimize self-quenching effects, tunable emission wavelength that extends to the near-infrared (NIR) region, and long emission lifetimes (1-30 $\mu \mathrm{s})$. The long-lived emission permits time-gated imaging that can eliminate intrinsic luminescence from living cells and tissues $[10,11]$. In addition, the ligand structures of iridium complex can be easily modified by using typical synthetic techniques, thus allowing easy modification of their optical and cellular properties [8].

The long-lived phosphorescence of iridium complexes are significantly quenched by ambient molecular oxygen through energy transfer and/or electron transfer from the lowest excited triplet state to ground state oxygen $[12,13]$. Utilizing the oxygen quenching behaviour of iridium complexes, attempts to develop solid-state oxygen sensors have been made by doping the complexes into a suitable polymer matrix [14-19]. As a biomedical application, we recently reported that an iridium(III) complex BTP ((btp $)_{2} \operatorname{Ir}(\mathrm{acac})$; btp = benzothienylpyridine, acac $=$ acetylacetone $)$ and its derivatives serve as a luminescent oxygen sensor for living cells and tissues [20-23]. Hypoxic tumor tissues of tumor-bearing mice could be visualized by BTP phosphorescence using the Maestro in vivo imaging system. It has also been shown that the phosphorescence intensity of BTP responds to oxygen levels in living cells. BTP can be taken up into living cells without using any transfection reagents. Lo et al. examined the cellular properties of iridium(III)-polyamine complexes and reported that these cationic complexes 
were mainly localized inside mitochondria [24,25]. Mitochondria consume the greatest amount of oxygen in cells to allow oxidative phosphorylation, which is the primary metabolic pathway for ATP production. Since the oxygen level in living cells is related to mitochondrial function and dysfunction with specific diseases [26-28], much attention has been paid to the development of analytical method to detect the oxygen status of mitochondria [29-35].

In this paper, we describe the synthesis, photophysical properties and oxygen response of a cationic iridium complex (btp) ${ }_{2} \operatorname{Ir}\left(\right.$ phen- $\left.\mathrm{NH}_{2}\right)$ (phen- $\mathrm{NH}_{2}=5$-amino-1,10-phenanthroline) and its analogues with extended $\pi$-electronic structures that were designed toward mitochondria-targeted oxygen probes. The chemical structures of these complexes are illustrated in Fig. 1 together with their abbreviations used in this paper. The iridium(III) complexes in Fig. 1 were synthesized according to the following design concept: the ligand 5-amino-1,10-phenanthroline was introduced to give a cationic charge to the complexes and thus to enhance cellular uptake efficiency and mitochondrial localization in cells; the $\pi$-conjugated system was extended in order to shift the emission wavelengths up to the NIR region, because NIR light permits imaging of deeper tissues [36]. The photophysical and cellular properties of these cationic iridium complexes were investigated by using their neutral analogues with an acetylacetonate (acac) ligand as reference compounds (Fig. 2).

\section{Experimental}

\subsection{Instruments}

Absorption and emission spectra were recorded on an UV/vis spectrophotometer (Jasco, Ubest-V550) and a photonic multichannel analyzer PMA-12 (Hamamatsu, C10027-01) equipped with a monochromatized Xe arc lamp, respectively. The emission spectrum was corrected for spectral sensitivity. Phosphorescence lifetimes of the iridium complexes in solution were measured with a time-correlated single-photon counting fluorometer 
(Hamamatsu, Quantaurus-Tau C11367). Phosphorescence quantum yield was measured with an absolute photoluminescence quantum yield system (Hamamatsu, C9920-01) [37] consisting of a Xe arc lamp, a monochromator, an integrating sphere, and a multichannel detector. Tetrahydrofuran (THF; Kanto, spectroscopic grade) was used as received. Deionized water was purified by using a Millipore (MILLI-Q-LABO).

Dimyristoyl-L- $\alpha$-phosphatidylcholine (DMPC; Sigma 99\%) was used for lipid membrane and liposome preparation. Small unilamellar vesicles were prepared by ethanol injection method [38]. The ethanolic solution of DMPC (30 mM, $0.1 \mathrm{ml})$ was injected rapidly into Tris- $\mathrm{HCl}$ buffer $(2.85 \mathrm{ml}, \mathrm{pH}=7.0)$ at $50^{\circ} \mathrm{C}$. The incorporation of iridium complex $\mathbf{2 b}$ into the small unilamellar vesicles was carried out by adding a stock solution of $\mathbf{2 b}(60 \mu \mathrm{M}, 0.05 \mathrm{ml})$ in DMSO. The final concentration of $\mathbf{2 b}$ was $1 \mu \mathrm{M}$. The solution was equilibrated for $1 \mathrm{~h}$ above the phase transition temperature $\left(23^{\circ} \mathrm{C}\right)$ of DMPC.

Human serum albumin (HSA; 96-99\%) was purchased from Sigma. HSA solution in Tris-HCl buffer $(\mathrm{pH}=7.0)$ was bubbled with oxygen-nitrogen mixed gas to adjust the dissolved oxygen concentration, and then a small amount of $\mathbf{2 b}$ solution in DMSO was added to the HSA solution. Final concentrations of $\mathbf{2 b}$ and HSA in Tris-HCl buffer/DMSO (98: 2, v/v) were $5 \mu \mathrm{M}$ and $200 \mu \mathrm{M}$, respectively. Oxygen quenching experiments were carried out for DMPC membrane-incorporated $\mathbf{2 b}$, and HSA-bound $\mathbf{2 b}$. Nitrogen-oxygen mixed gas regulated with a mass-flow meter (HORIBA STEC; SEC-V110DM, PAC-D2) was bubbled through the sample solution for 20 min prior to luminescence measurement.

\subsection{Cell culture and imaging}

Human uterine cancer-derived HeLa cells were cultured in Dulbecco's Modified Eagle Medium (DMEM, Gibco). These media were added to $10 \%$ fetal bovine serum, penicillin (50 units $/ \mathrm{ml})$ and streptomycin $(50 \mu \mathrm{g} / \mathrm{ml})$. All cells were grown at $37^{\circ} \mathrm{C}$ under a $5 \% \mathrm{CO}_{2}$ atmosphere. For $2.5 \% \mathrm{O}_{2}$ incubation of the cells, an oxygen concentration-changeable 
multi-gas incubator (Wakenyaku Ex 9200) was used.

For the imaging of living cells, the cells were seeded on glass-bottomed dishes, allowed to adhere for $24 \mathrm{~h}$, and then incubated with iridium(III) complex at the indicated concentrations and for the indicated durations. An inverted microscope (Olympus IX71) equipped with a x40 or a x100 oil-immersion objective lens and an electron multiplying CCD camera (Evolve 512, PHOTOMETRICS) driven by MetaMorph software were used to obtain luminescence microscope images. Samples were excited using a $100 \mathrm{~W}$ mercury lamp and imaged using custom filter settings.

\subsection{Cellular uptake}

HeLa cells $\left(3.0 \times 10^{4}\right.$ cells/well) were seeded into a 96-well flat bottom plate and allowed to adhere for $4 \mathrm{~h}$. The stock solution of iridium(III) complex was diluted with DMEM containing $10 \%$ fetal bovine serum, penicillin (50 units $/ \mathrm{ml})$, and streptomycin $(50 \mu \mathrm{g} / \mathrm{ml})$. The cells were incubated with iridium(III) complexes for $2 \mathrm{~h}$ at $37^{\circ} \mathrm{C}$ under a $5 \% \mathrm{CO}_{2}$ atmosphere. Then the medium was removed, the cells were washed 2 times with Hank's balanced salt solution (HBSS, Gibco). The measurements of phosphorescence signals of each iridium(III) complex were carried out by using a microplate reader (Infinite 200 PRO, TECAN).

\subsection{Cytotoxicity assay}

HeLa cells $\left(5.0 \times 10^{3}\right.$ cells/well) were seeded into a 96-well flat bottom plate and allowed to adhere for $4 \mathrm{~h}$. The stock solution of iridium(III) complex was diluted with DMEM containing $10 \%$ fetal bovine serum, penicillin (50 units/ml), and streptomycin $(50 \mu \mathrm{g} / \mathrm{ml})$. The cells were incubated with iridium(III) complexes for $4 \mathrm{~h}$ or $24 \mathrm{~h}$ at $37^{\circ} \mathrm{C}$ under a $5 \% \mathrm{CO}_{2}$ atmosphere. The medium was removed, and then the cells were washed gently with DMEM without phenol red. Cell counting kit-8 (CCK-8, Dojindo) was added to each well, and incubation was continued 
for $2 \mathrm{~h}$. The absorbance at $450 \mathrm{~nm}$ of each well referenced at $650 \mathrm{~nm}$ was recorded by using a microplate reader (Infinite 200 PRO, TECAN). Cell viability (\% of control) was evaluated as $\left(\mathrm{A}_{\text {sample }}-\mathrm{A}_{\text {blank }}\right) /\left(\mathrm{A}_{\text {control }}-\mathrm{A}_{\text {blank }}\right) \times 100$, where $\mathrm{A}_{\text {sample }}$ is the absorbance of cells exposed to iridium(III) complex, $\mathrm{A}_{\text {control }}$ is the absorbance of cells without iridium(III) complex, and $\mathrm{A}_{\text {blank }}$ is the absorbance of the wells without cells.

\subsection{Materials}

\subsubsection{General information}

All reagents and solvents for syntheses were purchased from Kanto Chemical, Wako Pure Chemical, Tokyo Chemical Industries, or Sigma-Aldrich, and were used without further purification. ${ }^{1} \mathrm{H}-\mathrm{NMR}$ spectra were recorded with a JNM-AL300 (JEOL) at $300 \mathrm{MHz}$ or a JNM-ECS400 (JEOL) at $400 \mathrm{MHz}$. Chemical shifts of ${ }^{1} \mathrm{H}-\mathrm{NMR}$ were referenced to tetramethylsilane. The apparent resonance multiplicity was described as s (singlet), d (doublet), $\mathrm{t}$ (triplet), and $\mathrm{m}$ (multiplet). ESI-MS measurements were carried out on an API 2000 (Applied Biosystems). Elemental analysis was performed with MICRO CORDER JM10 (J-SCIENCE).

Ligands of iridium(III) complexes in Figs. 1 and 2 were synthesized and identified according to the methods described in Supplementary Information.

\subsubsection{General synthetic procedure of iridium(III) complex with an acetylacetonate ligand}

Iridium(III) complexes with an acetylacetonate ligand were synthesized according to the literature [39]. Aromatic ligand (btp, btq, ttph, btph, $2.2 \mathrm{mmol})$ and $\mathrm{IrCl}_{3} \cdot 3 \mathrm{H}_{2} \mathrm{O}(1.0 \mathrm{mmol})$ were dissolved in 2-ethoxyethanol $(30 \mathrm{ml})$ and distilled water $(10 \mathrm{ml})$, and then the solution was heated at reflux for 15 hours. After cooling, the precipitate formed was filtered to give a chloro-bridged dimer and washed thoroughly with methanol and $n$-hexane. The chloro-bridged dimer $(0.1 \mathrm{mmol})$ was dissolved in 2-methoxyethanol $(25 \mathrm{ml})$, then 
acetylacetone $(1 \mathrm{ml})$ and triethylamine $(1 \mathrm{ml})$ were added. The solution was refluxed for 3 hours and evaporated to dryness under reduced pressure. The crude product was purified by silica-gel column chromatography using chloroform as eluent. The purity of complexes is determined to be more than $97 \%$ by using HPLC analysis (Fig. S1).

\subsection{3 (btp) $)_{2} \operatorname{Ir}($ acac)}

$63 \%$ yield. ${ }^{1} \mathrm{H}$ NMR (300 MHz, $\left.\mathrm{CDCl}_{3}\right) \delta: 8.43(\mathrm{~d}, 2 \mathrm{H}), 7.77(\mathrm{t}, 2 \mathrm{H}), 7.63(\mathrm{~d}, 4 \mathrm{H}), 7.07-6.99$ $(\mathrm{m}, 4 \mathrm{H}), 6.80(\mathrm{t}, 2 \mathrm{H}), 6.20(\mathrm{~d}, 2 \mathrm{H}), 5.26(\mathrm{~s}, 1 \mathrm{H}), 1.78(\mathrm{~s}, 6 \mathrm{H})$. ESI-MS calcd for $\mathrm{C}_{31} \mathrm{H}_{23} \mathrm{IrN}_{2} \mathrm{O}_{2} \mathrm{~S}_{2} \quad(\mathrm{M})^{+}, \quad 712.08$; found, 711.8. Elemental analysis calcd (\%) for $\mathrm{C}_{31} \mathrm{H}_{23} \mathrm{IrN}_{2} \mathrm{O}_{2} \mathrm{~S}_{2}$ : C, 52.30; H, 3.26; N, 3.94; found: C, 50.86; H, 3.24; N, 3.80 .

\subsection{4 (btq $)_{2} \operatorname{Ir}($ acac $)$}

79\% yield. ${ }^{1} \mathrm{H}$ NMR $\left(300 \mathrm{MHz}, \mathrm{CDCl}_{3}\right) \delta: 8.17-8.14(\mathrm{~d}, 2 \mathrm{H}), 8.01-7.98(\mathrm{~d}, 2 \mathrm{H}), 7.85-7.83(\mathrm{~d}$, 2H), 7.75-7.73 (d, 2H), 7.71-7.68 (d, 2H), 7.37-7.32 (t, 2H), 7.73-7.23 (t, 2H), 7.02-6.97 (t, 2H), 6.57-6.52 (t, 2H), 6.32-6.30 (d, 2H), $4.63(\mathrm{~s}, 1 \mathrm{H}), 1.55(\mathrm{~s}, 6 \mathrm{H})$. ESI-MS calcd for $\mathrm{C}_{39} \mathrm{H}_{27} \mathrm{IrN}_{2} \mathrm{O}_{2} \mathrm{~S}_{2} \quad(\mathrm{M}+\mathrm{Na})^{+}$, 835.11; found, 834.9. Elemental analysis calcd (\%) for $\mathrm{C}_{39} \mathrm{H}_{27} \mathrm{IrN}_{2} \mathrm{O}_{2} \mathrm{~S}_{2}:$ C, 57.69; H, 3.35; N, 3.45; found: C, 53.96; H, 3.09; N, 3.64.

\subsection{5 (ttph $)_{2} \operatorname{Ir}(\mathbf{a c a c})$}

51\% yield. ${ }^{1} \mathrm{H}$ NMR $\left(300 \mathrm{MHz}, \mathrm{CDCl}_{3}\right) \delta: 9.03-8.94(\mathrm{~m}, 5 \mathrm{H}), 8.71-8.69(\mathrm{t}, 2 \mathrm{H}), 8.04-8.01(\mathrm{~m}$, 5H), 7.52-7.39 (m, 3H), 7.29-7.27 (m, 2H), 7.26-7.20 (m, 2H), 7.19-7.17 (m, 2H), $4.76(\mathrm{~s}$, $1 \mathrm{H})$, 1.71(m, 6H). ESI-MS calcd for $\mathrm{C}_{43} \mathrm{H}_{27} \mathrm{IrN}_{2} \mathrm{O}_{2} \mathrm{~S}_{4}(\mathrm{M}+\mathrm{Na})^{+}$, 947.06; found, 946.6. Elemental analysis calcd (\%) for $\mathrm{C}_{43} \mathrm{H}_{27} \mathrm{IrN}_{2} \mathrm{O}_{2} \mathrm{~S}_{4}$ : C, 55.88; H, 2.94; N, 3.03; found: C, 56.71; H, 3.93; N, 2.92. 


\subsection{6 (btph) $)_{2} \operatorname{Ir}($ acac $)$}

80\% yield. ${ }^{1} \mathrm{H}$ NMR (300 MHz, $\mathrm{CDCl}_{3}$ ) $\delta: 9.35-9.33(\mathrm{~d}, 2 \mathrm{H}), 8.72-8.70$ (d, 2H), 8.46-8.44 (d, 2H), 7.98-7.87 (m, 4H), 7.85-7.82 (d, 2H), 7.73-7.70 (d, 2H), 7.43-7.38 (t, 2H), 7.20-7.15 (t, 2H), 7.04-6.99 (m, 2H), 6.52-6.51 (d, 4H), 4.50(s, 1H), 1.39(s, 6H). ESI-MS calcd for $\mathrm{C}_{47} \mathrm{H}_{31} \mathrm{IrN}_{2} \mathrm{O}_{2} \mathrm{~S}_{2} \quad(\mathrm{M}+\mathrm{Na})^{+}$, 935.15; found, 934.3. Elemental analysis calcd (\%) for $\mathrm{C}_{47} \mathrm{H}_{31} \mathrm{IrN}_{2} \mathrm{O}_{2} \mathrm{~S}_{2}$ : C, 61.89; H, 3.43; N, 3.07; found: C, 61.24; H, 3.64; N, 2.99.

\subsubsection{General synthetic procedure of cationic iridium(III) complexes with}

\section{1,10-phenanthroline derivatives}

A mixture of chloro-bridged dimer $(0.1 \mathrm{mmol})$ containing btp, btq, ttph or btph ligands and 1,10-phenanthroline derivatives $(0.22 \mathrm{mmol})$ in THF $(15 \mathrm{~mL})$ and methanol $(15 \mathrm{ml})$ was refluxed for 4 hours under a nitrogen atmosphere. After cooling, potassium hexafluorophosphate $\left(\mathrm{KPF}_{6}\right)$ was added to the solution. The solution was stirred for 1 hour at room temperature and then evaporated to dryness under reduced pressure. The crude product was purified by aluminum column chromatography using chloroform : methanol $(9: 1 \mathrm{v} / \mathrm{v})$ as eluent. The purity of complexes is determined to be more than $97 \%$ by using HPLC analysis (Fig. S1).

\subsection{8 (btp) ${ }_{2} \operatorname{Ir}\left(\right.$ phen- $\left.\mathrm{NH}_{2}\right)(1 \mathrm{a})$}

$48 \%$ yield. ${ }^{1} \mathrm{H}$ NMR (400 MHz, dmso) $\delta: 9.02-9.00(\mathrm{~d}, 1 \mathrm{H}), 8.41-8.38(\mathrm{~d}, 1 \mathrm{H}), 8.10-8.08(\mathrm{~d}$, 1H)7.95-7.87(m, 7H), 7.68-7.65(m, 2H), 7.46-7.42(dd, 2H), 7.22-7.17(t, 2H), 7.09(s, 1H), 6.99(s, 1H), 6.92-6.86(m, 4H), 5.98-5.93(s, 2H). ESI-MS calcd for $\mathrm{C}_{38} \mathrm{H}_{25} \mathrm{IrN}_{5} \mathrm{~S}_{2}\left(\mathrm{M}-\mathrm{PF}_{6}\right)^{+}$, 808.12; found, 807.8. Elemental analysis calcd (\%) for $\mathrm{C}_{38} \mathrm{H}_{25} \mathrm{~F}_{6} \mathrm{IrN}_{5} \mathrm{PS}_{2}$ : C, 47.89; H, 2.64; N, 7.35; found: C, 47.11; H, 2.98; N, 7.14. 


\subsection{9 (btp) ${ }_{2} \operatorname{Ir}($ phen-DMA) (1b)}

75\% yield. ${ }^{1} \mathrm{H}$ NMR $\left(400 \mathrm{MHz}, \mathrm{CDCl}_{3}\right) \delta:$ 8.84-8.82(d, $\left.1 \mathrm{H}\right), 8.48-8.45(\mathrm{~d}, 1 \mathrm{H}), 8.19-8.17(\mathrm{~d}$, 1H), 7.97-7.95(d, 1H), 7.81-7.59(m, 8H), 7.52(s, 1H), 7.35-7.27(m, 1H), 7.22-7.18(t, 2H), 6.09-6.04(dd, 2H), 3.07(s, 6H). ESI-MS calcd for $\mathrm{C}_{40} \mathrm{H}_{29} \mathrm{IrN}_{5} \mathrm{~S}_{2}(\mathrm{M}-\mathrm{PF})^{+}$, 836.15; found, 835.7. Elemental analysis calcd $(\%)$ for $\mathrm{C}_{40} \mathrm{H}_{29} \mathrm{~F}_{6} \mathrm{IrN}_{5} \mathrm{PS}_{2}$ : C, 48.97; H, 2.98; N, 7.14; found: C, 48.33; H, 3.26; N, 7.21.

\subsubsection{0 (btp) ${ }_{2} \operatorname{Ir}($ phen-DEA) (1c)}

$73 \%$ yield. ${ }^{1} \mathrm{H}$ NMR $\left(400 \mathrm{MHz}, \mathrm{CDCl}_{3}\right) \delta: 8.83-8.80(\mathrm{~d}, 1 \mathrm{H}), 8.51-8.49(\mathrm{~d}, 1 \mathrm{H}), 8.19-8.18(\mathrm{~d}$, 1H), 8.00-7.99(d, 1H), 7.82-7.63(m, 8H), 7.58(s, 1H), 7.34-7.30(m, 2H), 7.23-7.19(t, 1H), 6.90-6.81(m, 4H), 6.09-6.03(dd, 2H), 3.43-3.37(q, 4H), 1.20-1.17(t, 6H). ESI-MS calcd for $\mathrm{C}_{42} \mathrm{H}_{33} \mathrm{IrN}_{5} \mathrm{~S}_{2} \quad\left(\mathrm{M}-\mathrm{PF}_{6}\right)^{+}, \quad 864.18$; found, 863.8. Elemental analysis calcd (\%) for $\mathrm{C}_{42} \mathrm{H}_{33} \mathrm{~F}_{6} \mathrm{IrN}_{5} \mathrm{PS}_{2}$ : C, 49.99; H, 3.30; N, 6.94; found: C, 49.53; H, 3.42; N, 6.74.

\subsubsection{1 (btq) $)_{2} \operatorname{Ir}\left(\right.$ phen- $\left.\mathrm{NH}_{2}\right)(2 \mathrm{a})$}

80\% yield. ${ }^{1} \mathrm{H}$ NMR (400 MHz, $\left.\mathrm{CDCl}_{3}\right) \delta: 8.91-8.89(\mathrm{~d}, 1 \mathrm{H}), 8.57-8.56(\mathrm{~d}, 1 \mathrm{H}), 8.21-8.10(\mathrm{~m}$, 4H), 7.97-7.80(m, 6H), 7.57-7.48(m, 4H), 7.19-7.10(m, 4H), 6.92-6.85(dd, 2H), 6.76(s, 1H), 6.69-6.60(m, 5H), 6.38-6.30(m, 2H). ESI-MS calcd for $\mathrm{C}_{46} \mathrm{H}_{29} \mathrm{IrN}_{5} \mathrm{~S}_{2}\left(\mathrm{M}-\mathrm{PF}_{6}\right)^{+}, 908.15$; found, 907.7. Elemental analysis calcd (\%) for $\mathrm{C}_{46} \mathrm{H}_{29} \mathrm{~F}_{6} \mathrm{IrN}_{5} \mathrm{PS}_{2}$ : C, 52.47; H, 2.78; N, 6.65; found: C, 52.41; H, 3.11; N, 6.86 .

\subsubsection{2 (btq) $)_{2} \operatorname{Ir}($ phen-DMA) (2b)}

$30 \%$ yield. ${ }^{1} \mathrm{H}$ NMR (400 MHz, $\left.\mathrm{CDCl}_{3}\right) \delta: 8.68-8.56(\mathrm{~m}, 2 \mathrm{H}), 8.37-8.36(\mathrm{~d}, 2 \mathrm{H}), 8.15-8.10(\mathrm{t}$, 2H), 7.95-7.72(m, 6H), 7.55-7.49(m, 2H), 7.15-7.06(m, 3H), 6.97-6.92(m, 1H), 6.77(s, 1H), 6.63-6.57(m, 4H), 6.33-6.30(t, 2H), 3.72(s, 1H), 3.53-3.51(m, 1H), 2.85(s, 6H). ESI-MS calcd 
for $\mathrm{C}_{48} \mathrm{H}_{33} \mathrm{IrN}_{5} \mathrm{~S}_{2}\left(\mathrm{M}-\mathrm{PF}_{6}\right)^{+}$, 936.18; found, 935.7. Elemental analysis calcd (\%) for $\mathrm{C}_{48} \mathrm{H}_{33} \mathrm{~F}_{6} \mathrm{IrN}_{5} \mathrm{PS}_{2}$ : C, 53.33; H, 3.08; N, 6.48; found: C, 52.08; H, 3.20; N, 6.38.

\subsubsection{3 (btq) $)_{2} \operatorname{Ir}($ phen-DEA) (2c)}

$68 \%$ yield. ${ }^{1} \mathrm{H}$ NMR $\left(400 \mathrm{MHz}, \mathrm{CDCl}_{3}\right) \delta: 8.67-8.65(\mathrm{~d}, 1 \mathrm{H}), 8.59-8.58(\mathrm{~d}, 1 \mathrm{H}), 8.42-8.38(\mathrm{~m}$, 2H), 8.16-8.10(dd, 2H), 7.97-7.74(m, 7H), 7.57-7.50(m, 2H), 7.17-7.05(m, 4H), 6.77-6.57(m, $6 \mathrm{H}), 6.37-6.32(\mathrm{dd}, 2 \mathrm{H}), 3.18-3.13(\mathrm{dd}, 4 \mathrm{H}), 1.27-1.25(\mathrm{t}, 6 \mathrm{H})$. ESI-MS calcd for $\mathrm{C}_{50} \mathrm{H}_{37} \mathrm{IrN}_{5} \mathrm{~S}_{2}$ $\left(\mathrm{M}-\mathrm{PF}_{6}\right)^{+}, 964.21$; found, 964.2. Elemental analysis calcd (\%) for $\mathrm{C}_{50} \mathrm{H}_{37} \mathrm{~F}_{6} \mathrm{IrN}_{5} \mathrm{PS}_{2}: \mathrm{C}, 54.14$; H, 3.36; N, 6.31; found: C, 52.25; H, 3.43; N, 6.00 .

\subsubsection{4 (ttph) $)_{2} \operatorname{Ir}\left(\right.$ phen- $\left.\mathrm{NH}_{2}\right)(3 \mathrm{a})$}

$19 \%$ yield. ${ }^{1} \mathrm{H}$ NMR (400 MHz, DMSO) $\delta: 9.22-9.16(\mathrm{~m}, 2 \mathrm{H}), 8.86-8.48(\mathrm{~m}, 4 \mathrm{H}), 8.5-8.47(\mathrm{~m}$, $3 \mathrm{H}), 8.07-8.05(\mathrm{~m}, 4 \mathrm{H}), 7.98-7.92(\mathrm{~m}, 1 \mathrm{H}), 7.65-7.6(\mathrm{~m}, 1 \mathrm{H}), 7.43-7.3(\mathrm{~m}, 8 \mathrm{H}), 6.75-6.67(\mathrm{~m}$, 4H), 5.04(s, 2H). ESI-MS calcd for $\mathrm{C}_{50} \mathrm{H}_{29} \mathrm{IrN}_{5} \mathrm{~S}_{4}\left(\mathrm{M}-\mathrm{PF}_{6}\right)^{+}, 1020.09$; found, 1019.7 . Elemental analysis calcd (\%) for $\mathrm{C}_{50} \mathrm{H}_{29} \mathrm{~F}_{6} \mathrm{IrN}_{5} \mathrm{PS}_{4}$ : C, 51.54; H, 2.51; N, 6.01; found: C, 51.60; H, 2.77; N, 6.64 .

\subsubsection{5 (ttph) $)_{2} \operatorname{Ir}($ phen-DMA) (3b)}

$21 \%$ yield. ${ }^{1} \mathrm{H}$ NMR $\left(400 \mathrm{MHz}, \mathrm{CDCl}_{3}\right) \delta: 9.28-9.23(\mathrm{~m}, 2 \mathrm{H}), 8.86-8.85(\mathrm{~m}, 1 \mathrm{H}), 8.62-8.58(\mathrm{~m}$, 5H), 8.36-8.23(m,4H),8.02-7.91(m, 5H), 7.82-7.78(m,1H), 7.67-7.62(m,1H), 7.37-7.34(m, $1 \mathrm{H}), 7.25-7.20(5 \mathrm{H}), 6.69-6.58(\mathrm{~m}, 2 \mathrm{H}), 2.86(\mathrm{~s}, 6 \mathrm{H})$. ESI-MS calcd for $\mathrm{C}_{52} \mathrm{H}_{33} \mathrm{IrN}_{5} \mathrm{~S}_{4}\left(\mathrm{M}-\mathrm{PF}_{6}\right)^{+}$, 1048.12; found, 1047.9. Elemental analysis calcd (\%) for $\mathrm{C}_{52} \mathrm{H}_{33} \mathrm{~F}_{6} \mathrm{IrN}_{5} \mathrm{PS}_{4}$ : C, 52.34; H, 2.79; N, 5.87; found: C, 52.25; H, 3.02; N, 5.95.

\subsubsection{6 (btph $)_{2} \operatorname{Ir}\left(\right.$ phen- $\left.\mathrm{NH}_{2}\right)(4 \mathrm{a})$}


24\% yield. ${ }^{1} \mathrm{H}$ NMR (400 MHz, $\mathrm{CDCl}_{3}$ ) $8: 9.41-9.40(\mathrm{~m}, 3 \mathrm{H}), 8.85-8.84(\mathrm{~d}, 1 \mathrm{H}), 8.61-8.60(\mathrm{~d}$, 1H), 8.53-8.47(m, 2H),8.44-8.40(d, 1H), 8.14-8.16(t, 2H), 7.98-7.89(m, 7H), 7.70-7.68(m, 1H), 7.40-7.36(m, 1H), 7.21-7.12(m, 5H), 6.77-6.75(m, 2H), 6.68-6.58(m, 5H), 5.04(s, 2H). ESI-MS calcd for $\mathrm{C}_{54} \mathrm{H}_{33} \mathrm{IrN}_{5} \mathrm{~S}_{2}\left(\mathrm{M}-\mathrm{PF}_{6}\right)^{+}, 1008.18$; found, 1007.9. Elemental analysis calcd (\%) for $\mathrm{C}_{54} \mathrm{H}_{33} \mathrm{~F}_{6} \mathrm{IrN}_{5} \mathrm{PS}_{2}$ : C, 56.24; H, 2.88; N, 6.07; found: C, 55.54; H, 3.02; N, 6.07.

\subsubsection{7 (btph) $)_{2} \operatorname{Ir}($ phen-DMA) (4b)}

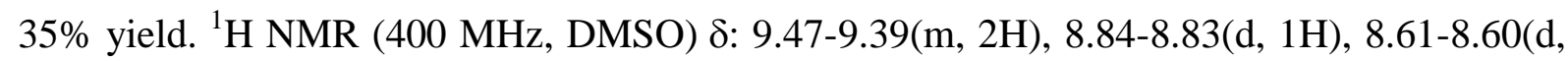
1H), 8.54-8.49(m, 3H),8.25-8.28(d, $1 \mathrm{H}), 8.16-8.14(\mathrm{~m}, 2 \mathrm{H}), 8.01-7.89(\mathrm{~m}, 6 \mathrm{H}), 7.73-7.70(\mathrm{q}$, 1H), 7.59-7.55(q, 1H), 7.34-7.31(m, 1H), 7.20-7.10(m, 6H), 6.78-6.61(m, 4H), 6.57-6.53(t, 2H), 2.76(s, 6H). ESI-MS calcd for $\mathrm{C}_{56} \mathrm{H}_{37} \mathrm{IrN}_{5} \mathrm{~S}_{2}\left(\mathrm{M}-\mathrm{PF}_{6}\right)^{+}, 1036.21$; found, 1035.7 . Elemental analysis calcd (\%) for $\mathrm{C}_{56} \mathrm{H}_{37} \mathrm{~F}_{6} \mathrm{IrN}_{5} \mathrm{PS}_{2}$ : C, 56.94; H, 3.16; N, 5.93; found: C, 55.42; H, 3.27; N, 5.72 .

\section{Results and discussion}

\subsection{Photophysical properties in solution}

We first elucidated the spectral and photophysical properties of the iridium complexes synthesized in the present work. Figure 3 shows the absorption and phosphorescence spectra of (btp) $)_{2} \operatorname{Ir}\left(\right.$ phen- $\left.\mathrm{NH}_{2}\right)(\mathbf{1 a})$, the alkylated derivatives of $\mathbf{1 a}(\mathbf{1 b}$ and $\mathbf{1 c})$ and their $\pi$-extended analogues $\mathbf{2 a}, \mathbf{3 a}$ and $\mathbf{4 a}$ in THF together with those of (btp) ${ }_{2} \operatorname{Ir}(\mathrm{acac})(\mathrm{BTP})$. The absorption band of BTP with the maximum at $486 \mathrm{~nm}$ has been assigned to the transition from the ground state to the first singlet metal-to-ligand charge transfer $\left({ }^{1} \mathrm{MLCT}\right)$ state, while the emission spectrum with the maximum at $615 \mathrm{~nm}$ is attributable to phosphorescence as being largely of ligand (btp)-centered triplet $\pi \pi^{*}$ parentage with significant admixtures of the triplet metal-to-ligand charge transfer $\left({ }^{3} \mathrm{MLCT}\right)$ character $\left(\mathrm{d} \pi(\mathrm{Ir}) \rightarrow \pi^{*}(\mathrm{btp})\right)[40,41]$. The first 
absorption band of the cationic complex 1a is blue shifted by $45 \mathrm{~nm}$, and the phosphorescence maximum shows a blue shift of $22 \mathrm{~nm}$ relative to those of BTP (Fig. $3 \mathrm{~b}$ and Table 1). These blue shifts are probably related to the cationic charge in 1a-c which might stabilize their HOMO levels compared to the neutral complex BTP. It can be seen from Table 1 that the molar absorption coefficients of the first absorption band of the complexes with a 5-amino-1,10-phenanthroline ligand are increased as compared with those of their acac analogues. Dimethylation and diethylation of the amino group in (btp) ${ }_{2} \operatorname{Ir}\left(\right.$ phen- $\left.\mathrm{NH}_{2}\right)$ scarcely affect the spectral properties as seen in Fig. 3b-d. The structured emission spectra and long phosphorescence lifetime (described below) suggest that the lowest triplet state of 1a-c also has ligand-centered ${ }^{3} \pi \pi^{*}$ character $\left(\pi \rightarrow \pi^{*}\left(\mathrm{~N}^{\wedge} \mathrm{C}\right.\right.$ and $\left.\left.\mathrm{N}^{\wedge} \mathrm{N}\right)\right)$ with mixing of ${ }^{3}$ MLCT $(\mathrm{d} \pi$ $(\mathrm{Ir}) \rightarrow \pi^{*}\left(\mathrm{~N}^{\wedge} \mathrm{C}\right.$ and $\left.\left.\mathrm{N}^{\wedge} \mathrm{N}\right)\right)$. The significant red shifts observed for the phosphorescence spectra of 2a, 3a and 4a (Fig. 3e-g) in comparison to 1a suggest that the phosphorescent states of 1a-4a originate mainly from the intraligand $\pi \pi^{*}$ transitions in the $\mathrm{N}^{\wedge} \mathrm{C}$ ligand admixed with ${ }^{3}$ MLCT. The phosphorescence bands of 3a and $\mathbf{4 a}$ appear in the near-infrared region that is beneficial for tissue penetrance in in vivo measurements [36]. Despite the long-wavelength emission, the phosphorescence quantum yields $\left(\Phi_{\mathrm{p}}^{0}\right)$ of $\mathbf{3 a}$ and $\mathbf{4 a}$ are not significantly decreased and moderately high ( 0.24 and 0.14 , respectively in degassed THF) (Table 1$)$. The absorption and phosphorescence spectra of $\mathbf{2 b}, \mathbf{2 c}, \mathbf{3 b}$ and $\mathbf{4 b}$ together with their neutral analogues are shown in Fig. S2.

The photophysical properties of the iridium complexes in Figs. 1 and 2 are summarized in Table 1. The phosphorescence lifetimes $\left(\tau_{\mathrm{p}}^{0}=7.5-8.6 \mu \mathrm{s}\right)$ of 1a-c in degassed THF are longest of the complexes in Table 1. The longer lifetimes of 1a-c might originate from the increase of the $\pi \pi^{*}$ character in the emitting state as suggested by the smaller phosphorescence radiative rate constant $\left(k_{\mathrm{p}}\right)$ values that were evaluated from the 
phosphorescence quantum yields $\left(\Phi_{\mathrm{p}}^{0}\right)$ and lifetime $\left(\tau_{\mathrm{p}}^{0}\right)$ in degassed solutions by using the relation $k_{\mathrm{p}}=\Phi_{\mathrm{p}}^{0} / \tau_{\mathrm{p}}^{0}$, where the quantum yield of intersystem crossing $\left(\Phi_{\mathrm{isc}}\right)$ is assumed to be unity [42].

The phosphorescence quenching due to molecular oxygen can be evaluated by using the Stern-Volmer equation:

$$
\frac{\Phi_{\mathrm{p}}^{0}}{\Phi_{\mathrm{p}}}=\frac{\tau_{\mathrm{p}}^{0}}{\tau_{\mathrm{p}}}=1+k_{\mathrm{q}} \tau_{\mathrm{p}}^{0} p \mathrm{O}_{2}=1+K_{\mathrm{SV}} p \mathrm{O}_{2}
$$

where $\Phi_{\mathrm{p}}$ and $\tau_{\mathrm{p}}$, respectively, are the phosphorescence quantum yield and lifetime at an oxygen partial pressure $p \mathrm{O}_{2}$, and $k_{\mathrm{q}}$ and $K_{\mathrm{SV}}$, respectively, are the bimolecular quenching rate constant and Stern-Volmer constant. It can be seen from Table 1 that in spite of the longer $\tau_{\mathrm{p}}^{0}$ of 1a-c, their oxygen response, which is evaluated by the ratio of the phosphorescence lifetimes in degassed and aerated conditions $\left(\tau_{\mathrm{p}}^{0} / \tau_{\mathrm{p}}(21 \%)\right)$ are reduced by about half compared with that of BTP. The decrease in the oxygen responses in 1a-c could be ascribed to the decrease in the oxygen quenching rate constant: $6.2 \times 10^{9} \mathrm{M}^{-1} \mathrm{~s}^{-1}$ for BTP and $2.4 \times 10^{9}$ $\mathrm{M}^{-1} \mathrm{~s}^{-1}$ for $\mathbf{1 a}$ in acetonitrile at $298 \mathrm{~K}$.

The absorption and phosphorescence maxima of 2a-2c shift greatly to the blue compared with those of (btq) $)_{2} \operatorname{Ir}(\mathrm{acac})$, whereas the phosphorescence quantum yields $\left(\Phi_{\mathrm{p}}^{0}\right)$ are almost equal to that of (btq) $)_{2} \operatorname{Ir}(\mathrm{acac})$ (Table 1). Although the phosphorescence lifetimes $\left(\tau_{\mathrm{p}}^{0}\right)$ of 2a-2c become much longer than that of (btq) $)_{2} \operatorname{Ir}(\mathrm{acac})$, the oxygen responses $\left(\tau_{\mathrm{p}}^{0} / \tau_{\mathrm{p}}(21 \%)\right)$ are slightly reduced relative to that of (btq) $)_{2} \operatorname{Ir}(\mathrm{acac})$. The absorption and phosphorescence maxima of 3a and 3b exhibit only slight blue shifts compared with those of (ttph $)_{2} \operatorname{Ir}(\mathrm{acac})$. The phosphorescence quantum yields $\left(\Phi_{\mathrm{p}}^{0}\right)$ of $\mathbf{3 a}$ and $\mathbf{3 b}$ are moderately decreased. The phosphorescence lifetimes $\left(\tau_{\mathrm{p}}^{0}\right)$ of $\mathbf{3 a}$ and $\mathbf{3 b}$ become much longer than that of $(\operatorname{ttph})_{2} \operatorname{Ir}(\mathrm{acac})$. 
However, the oxygen responses are almost equal to that of (ttph) $)_{2} \operatorname{Ir}(\mathrm{acac})$, probably due to decreases in the quenching rate constant. The first absorption bands of $\mathbf{4 a}$ and $\mathbf{4 b}$ shift only slightly to the red compared with that of $(\mathrm{btph})_{2} \operatorname{Ir}(\mathrm{acac})$, while the phosphorescence maxima show blue shifts. The phosphorescence quantum yields are reduced compared with that of (btph $)_{2} \operatorname{Ir}(\mathrm{acac})$, while the phosphorescence lifetimes $\left(\tau_{\mathrm{p}}^{0}\right)$ show little increases. Owing to the short lifetimes, the oxygen responses of $\mathbf{4 a}$ and $\mathbf{4 b}$ are found to become lower than the other complexes.

Comparison of three groups $\mathbf{1 a - c}, \mathbf{2 a - c}$ and $\mathbf{4 a - b}$ in Table 1 which have a benzothienyl moiety in the ligand shows that the oxygen response decreases in order of increasing the size of $\pi$-conjugated systems. The reduction of the oxygen response can be attributed to the increase in the $k_{\mathrm{p}}$ and $k_{\mathrm{isc}}^{\prime}$ values which results in the decrease of the lifetime $\tau_{\mathrm{p}}^{0}$. Here the enhancement in the nonradiative rate $\left(k_{\mathrm{isc}}^{\prime}\right)$ with an increase of $\pi$-conjugated systems can be explained by the energy gap law. The replacement of the benzothienyl group in $\mathbf{4 a}$ and $\mathbf{4 b}$ by the thienothiophenyl group (3a and $\mathbf{3 b}$ ) significantly increases $\tau_{\mathrm{p}}^{0}$ and consequently the oxygen responses.

\subsection{Interactions with lipid bilayer membranes and human serum albumin}

The iridium complexes in Fig. 1 are lipophilic, and their solubility to water is significantly low. They are, therefore, expected to be localized in plasma membrane and/or organelle membranes when loaded into cells. In order to evaluate the affinity of cationic iridium complexes with lipid membranes, we examined the partition of $\mathbf{2} \mathbf{b}$ into an artificial membrane composed of dimyristoyl-L- $\alpha$-phosphatidylcholine (DMPC). Since the DMPC membrane undergoes phase transition at approximately $23^{\circ} \mathrm{C}$, when in equilibrium with water, the experiments were performed at $37{ }^{\circ} \mathrm{C}$, i.e. for the liquid crystal state. Figure $4 \mathrm{a}$ shows the 
phosphorescence spectra of $\mathbf{2 b}(1 \mu \mathrm{M})$ with and without DMPC membrane in Tris-HCl buffer solution at $37{ }^{\circ} \mathrm{C}$. With increasing the concentrations of DMPC, the intensity of the phosphorescence increases significantly, indicating that $\mathbf{2 b}$ is incorporated into DMPC membrane. Here the phosphorescence enhancement can be attributed to the difference in the phosphorescence quantum yield of $\mathbf{2} \mathbf{b}$ in the buffer solution and DMPC membrane. In order to obtain the partition coefficient $\left(K_{\mathrm{p}}\right)$ of $\mathbf{2} \mathbf{b}$ between the buffer solution and DMPC membrane, the phosphorescence intensities of $\mathbf{2} \mathbf{b}$ at the peak wavelengths are plotted as a function of DMPC concentrations as shown in Fig. $4 \mathrm{~b}$. Here $K_{\mathrm{p}}$ represents the ratio of molar concentrations of $\mathbf{2 b}$ in the buffer solution and DMPC membrane. Since the phosphorescence quantum yield of $\mathbf{2 b}$ in the DMPC membrane is larger than that in the Tris- $\mathrm{HCl}$ buffer solution, the partition coefficient of $\mathbf{2} \mathbf{b}$ into the DMPC membrane can be obtained from the phosphorescence intensity (I) using Eq. (2) [43].

$$
I=\frac{I_{\mathrm{w}}+K_{\mathrm{p}} \gamma_{\mathrm{DMPC}}[\mathrm{DMPC}] I_{\mathrm{DMPC}}}{1+K_{\mathrm{p}} \gamma_{\mathrm{DMPC}}[\mathrm{DMPC}]}
$$

where $I_{\mathrm{W}}$ and $I_{\mathrm{DMPC}}$ are the limit phosphorescence intensities with all the $\mathbf{2} \mathbf{b}$ molecules in water and in the DMPC membrane, respectively, $\gamma_{\mathrm{DMPC}}$ is the molar volume of the DMPC (0.67 $\left.\mathrm{L} \mathrm{mol}^{-1}[44]\right)$, and [DMPC] is the DMPC concentration. From nonlinear regression analysis of the experimental data in Fig. $4 \mathrm{~b}, K_{\mathrm{p}}$ was obtained to be $1.6 \times 10^{5}$. It can be estimated from the value of the partition coefficient that over $99 \%$ of $\mathbf{2 b}$ is partitioned into the DMPC membrane $(1 \mathrm{mM})$ when $\mathbf{2 b}(1 \mu \mathrm{M})$ is dissolved in Tris- $\mathrm{HCl}$ buffer at $37{ }^{\circ} \mathrm{C}$. This suggests that iridium complexes in Fig. 1 are likely to accumulate in organelle membranes after passing through the plasma membrane of biological cells.

Figure 5a shows the phosphorescence decay curves of $\mathbf{2} \mathbf{b}$ in DMPC liposome membranes in Tris- $\mathrm{HCl}$ buffer $(\mathrm{pH}=7.0)$ for the various oxygen partial pressures. The phosphorescence decay curves could be analyzed as single exponential decay function. The oxygen-quenching 
rate constant $\left(k_{\mathrm{q}}\right)$ of $\mathbf{2 b}$ in DMPC liposome membranes in Tris- $\mathrm{HCl}$ buffer $(\mathrm{pH}=7.0)$ was obtained as $7.3 \times 10^{3} \mathrm{mmHg}^{-1} \mathrm{~s}^{-1}\left(1.2 \times 10^{9} \mathrm{M}^{-1} \mathrm{~s}^{-1}\right)$ by plotting $\tau_{\mathrm{p}}^{0} / \tau_{\mathrm{p}}$ against the oxygen partial pressure $p \mathrm{O}_{2}$ (the oxygen concentrations in the DMPC membrane) as shown in Fig. 5b (Fig. S3). The oxygen-quenching rate constant of $\mathbf{2 b}$ was found to be slightly smaller than that $\left(1.2 \times 10^{4} \mathrm{mmHg}^{-1} \mathrm{~s}^{-1}\right)$ of BTP in DMPC liposome membranes [20], consistent with the relative oxygen responses of $\mathbf{2 b}$ and BTP in THF evaluated by $\left(\tau_{\mathrm{p}}^{0} / \tau_{\mathrm{p}}(21 \%)\right)$ (Table 1$)$.

We then examined interactions of $\mathbf{2} \mathbf{b}$ with human serum albumin (HSA) in Tris-HCl buffer ( $\mathrm{pH}=7.0)$. Under the presence of HSA $(200 \mu \mathrm{M})$, the phosphorescence decay curves could be analyzed in terms of two exponential decay terms with lifetimes of $\tau_{1}$ and $\tau_{2}$, and relative amplitudes $A_{1}$ and $A_{2}$, respectively, as shown in Fig. S4 and Table 2. Two component lifetimes suggest that $\mathbf{2 b}$ is incorporated into two distinct binding domains in HSA. The amplitude average lifetime $\left\langle\tau_{\mathrm{p}}>\right.$ estimated from $A_{1} \tau_{1}+A_{2} \tau_{2}$ were $3.65 \mu$ s and $5.44 \mu$ s for the aerated and nitrogen-saturated solutions, respectively. The Stern-Volmer plot for $\left\langle\tau_{\mathrm{p}}^{0}\right\rangle \mid\left\langle\tau_{\mathrm{p}}\right\rangle$ as a function of $p \mathrm{O}_{2}$ gave a straight line (Fig. S5), and the oxygen quenching rate constant $k_{\mathrm{q}}$ in HSA was obtained to be $3.3 \times 10^{2} \mathrm{mmHg}^{-1} \mathrm{~s}^{-1}$ which was much smaller than that $\left(7.3 \times 10^{3}\right.$ $\mathrm{mmHg}^{-1} \mathrm{~s}^{-1}$ ) in DMPC membranes. Similar decrease of the oxygen quenching rate constant in albumin has also been reported for the phosphorescence of Pd-meso-tetra-(4-carboxyphenyl)tetrabenzoporphyrin [45]. These results suggest that the phosphorescence quenching of the cationic iridium complexes in Fig. 1 due to molecular oxygen is depressed by interactions with proteins in cells.

\subsection{Cellular uptake and oxygen response in living cells}

We examined the cellular uptake of $\mathbf{1 a - 1} \mathbf{c}$ and $\mathbf{2 b - 4 b}$ into human uterine cancer-derived HeLa cells by observing their phosphorescence microscope images which are shown in Fig. 6A with 
that of BTP. HeLa cells were incubated with these iridium complexes for $4 \mathrm{~h}$ at $37^{\circ} \mathrm{C}$ under $2.5 \% \mathrm{O}_{2}$ condition and the phosphorescence images were taken with an exposure time of 500 ms. Figure 5A indicates that these iridium complexes are readily taken up into the cells without the addition of chemical agents to assist membrane permeability. Similar phosphorescence images were obtained for the other complexes $\mathbf{2 a}, \mathbf{2 c}, \mathbf{3 a}$ and $\mathbf{4 a}$ (Fig. S6A). The iridium complexes $\mathbf{1 b}-\mathbf{4 b}$ and the other complexes exhibited oxygen responses in HeLa cells (Fig. 5B and Fig. S6B): the brightness of the phosphorescence images of $\mathbf{1 b}-\mathbf{4 b}$ was significantly enhanced when the oxygen pressure in the incubator was reduced from normoxia (21\%) to hypoxia (2.5\%) (Fig. 6B).

We next examined the cellular uptake and oxygen response of iridium complexes in HeLa cells by using a microplate reader (Fig. 7). Figure 6a shows the emission intensities of HeLa cells incubated with BTP and $1 \mathrm{a}(500 \mathrm{nM})$ for $2 \mathrm{~h}$ at $37^{\circ} \mathrm{C}$ under $2.5 \% \mathrm{O}_{2}$. The HeLa cells were excited at $465 \mathrm{~nm}$ (band width: $9 \mathrm{~nm}$ ) and the emission was observed at $607 \mathrm{~nm}$ (band width: $20 \mathrm{~nm}$ ) by using a monochromator. At these wavelengths the absorption spectra and the normalized emission spectra of BTP and 1a intersect with each other (Fig. S7). Taking the difference in $\Phi_{\mathrm{p}}^{0}$ (Table 1) into account, it can be expected from Fig. 7a that 1a has almost equivalent cellular uptake efficiency to that of BTP. Dimethyl (1b-4b) or diethyl (1c and 2c) derivatives of 1a-4a show remarkable enhancement in the emission intensities compared with those of 1a-4a under both $21 \%$ and $2.5 \% \mathrm{O}_{2}$ conditions. This reveals that dimethyl or diethyl derivatives of 1a-4a have much higher cellular uptake efficiencies compared with 1a-4a and BTP. These findings suggest that the cellular uptake efficiency of these complexes is facilitated by cooperation between the cationic charge and lipophilicity.

The emission intensity of $\mathbf{1 a - 4 b}$ in HeLa cells increased when the oxygen concentration was reduced from $21 \%$ to $2.5 \%$ (Fig. 7). However, the intensity ratios were only about 2.0 or less. By using eq. 1 and $\tau_{\mathrm{p}}^{0} / \tau_{\mathrm{p}}(21 \%)$ values in Table 1 , one can roughly estimate the $K_{\mathrm{sv}}$ 
values of each iridium complexes, and $\tau_{\mathrm{p}}(2.5 \%) / \tau_{\mathrm{p}}(21 \%)$ can be calculated as shown in Table 1. Comparing the results in Fig. 7 with $\tau_{\mathrm{p}}(2.5 \%) / \tau_{\mathrm{p}}(21 \%)$ in Table 1, it can be deduced that the oxygen responses of these iridium complexes in HeLa cells are significantly reduced as compared with those in solution. This finding suggests that lipophilic iridium complexes $\mathbf{1 a}-\mathbf{4 b}$, which are accumulated in organelle membranes, interact with membrane proteins. As a result, oxygen sensitivity might be reduced compared with that in solutions. The lower oxygen levels in living cells can also be responsible for the reduced oxygen response of iridium complexes in cells.

Optical oxygen sensors for isolated mitochondria have been developed for continuously sensing respiratory activity of mitochondria [29,46]. To examine mitochondrial oxygen tension, Mik et al have utilized the delayed fluorescence of protoporphyrin IX which was produced by endogenous synthesis in mitochondria [32-34]. They applied its precursor 5-aminolevulinic acid to cells to enhance signal intensity. In spite of the importance of detecting the oxygen status of mitochondria, there are few exogenous probes which can be used for mitochondria-selective oxygen sensing in living cells. We have developed a mitochondria-selective oxygen probe BTP-Mito which bears a triphenylphosphonium cation on the acac ligand of BTP [23]. By using HeLa cells stained with BTP-Mito, we demonstrated specific localization of BTP-Mito into mitochondria and oxygen response in cells. Very recently, Wang et al have developed phosphorescent nanosensors for intramitochondrial oxygen sensing [35]. Using these nanosensors, they have successfully assessed tumor mitochondrial dysfunction. Mitochondria-targeted oxygen probes developed in the present study are based on the cationic iridium complexes. These small molecular probes allow efficient cellular uptake and selective localization in mitochondria. Furthermore, the emission wavelengths extend to the NIR region, which permits imaging of deeper tissues compared to visible light. 


\subsection{Subcellular localization and cytotoxicity}

We verified the intracellular localization of the iridium complexes 1a-4b in living cells by morphologic examination using HeLa cells. Figure 8 shows the results on the iridium complex 1b. HeLa cells pretreated with the complex 1b (100 nM, $3.5 \mathrm{~h})$ were coincubated with the green-colored Mitochondria-specific probe (Mito tracker), ER-specific probe (ER tracker) or the lysosome-specific probe (Lyso tracker). The cellular image with $\mathbf{1 b}$ showed merged yellow color, i.e. significant overlap with Mito tracker (Fig. 8a). However, no green-colored ER tracker and Lyso tracker merged with 1b (Fig. 8b and 8c). These costaining experiments indicate that the iridium complex $\mathbf{1 b}$ internalized in living HeLa cells is predominantly enriched in mitochondria. The tubular-shaped structures of the emission image in Fig. 8a, which is the characteristic shape of mitochondria, also support mitochondrial localization of $\mathbf{1 b}$. Similar experiments on the other iridium complexes also suggested mitochondria-specific localization for HeLa cells (Figs. S8-S16). Delocalized lipophilic cations are known to preferentially accumulate in mitochondria in response to negatively charged intra-transmembrane potentials [47-49]. We could actually developed a mitochondria-specific iridium complex BTP-Mito [23] by incorporating a cationic triphenylphosphonium moiety into the acetylacetonato ligand of BTP. The present study show that cationic iridium complexes with a 5-amino-1,10-phenanthroline ligand and its alkylated analogues have a general tendency to preferentially accumulate in mitochondria.

The cytotoxicity of all the complexes towards HeLa cells over an incubation period of $24 \mathrm{~h}$ was examined using WST assays. Cell viability against the concentration of the iridium complexes in the cell medium is shown in Figs. S17 and S18, and the $\mathrm{IC}_{50}$ value of each complex was determined as listed in Table 3 . It is noteworthy that the $\mathrm{IC}_{50}$ values correlate with the cellular uptake efficiency of these complexes (Fig. 7). The $\mathrm{IC}_{50}$ values of these 
complexes are of the same order of magnitude as other cationic iridium(III) complexes [50]. Under typical experimental conditions for live cell imaging using these complexes, no significant cytotoxicity was found as shown in Fig. S19.

\section{Conclusion}

In order to develop mitochondria-targeted oxygen probes, we designed and synthesized a cationic iridium complex (btp) ${ }_{2} \operatorname{Ir}\left(\right.$ phen- $\left.\mathrm{NH}_{2}\right)$ (1a) and related complexes. By extending the $\pi$-electronic system of the btp ligand in 1a, we could obtain near-infrared emitting iridium complexes (ttph $)_{2} \operatorname{Ir}\left(\right.$ phen- $\left.\mathrm{NH}_{2}\right) \quad$ (3a) and (btph $)_{2} \operatorname{Ir}\left(\right.$ phen- $\left.\mathrm{NH}_{2}\right)$ (4a). The photophysical parameters of 1a-4a and their dialkylamino derivatives in THF solution were revealed together with the oxygen response of the phosphorescence lifetime in solution. By using (btq) $)_{2} \operatorname{Ir}($ phen-DMA) (2b) as a representative of iridium complexes in Fig. 1, we examined the interactions of $\mathbf{2 b}$ with DMPC membranes and human serum albumin. The oxygen quenching rate constant $\left(k_{\mathrm{q}}\right)$ of $\mathbf{2} \mathbf{b}$ phosphorescence decreased remarkably by binding to hydrophobic domain of HSA compared with that in DMPC membranes. The complexes 1a-4a were internalized into HeLa cells without the use of transfection reagents. Dialkylation of the amino group in 1a-4a significantly enhanced the cellular uptake efficiency. The iridium complexes with a 5-amino-1,10-phenanthroline ligand synthesized in the present study exhibited mitochondrial distribution and the phosphorescence intensity showed oxygen responses in HeLa cells. The oxygen response of all the complexes studied was significantly reduced in HeLa cells in comparison to that in solution and DMPC membranes, suggesting that the cationic iridium complexes interact with membrane proteins in cells. Owing to the high cellular uptake efficiency, greater cytotoxicity was found for the cationic iridium complexes with dialkylamino group. The present study show that under mild loading conditions iridium complexes $\mathbf{1 a - 4 b}$ can be utilized for mitochondria-selective oxygen 
probes.

\section{Acknowledgements}

ST acknowledges support from a Grant-in-Aid for Industry-Academia Collaborative R\&D Programs (In vivo Molecular Imaging: Towards Biophotonics Innovations in Medicine) from the Japan Science and Technology Agency, and a Grant-in-Aid for Scientific Research from the Ministry of Education, Culture, Sports, Science and Technology of Japan (No. 23310157). TY was financially supported by a Grant-in-Aid from The Canon Foundation.

Appendix A. Supplementary data associated with this article can be found, in the online version, at http://dx.doi.org/10.1016/j.jphoto- chem.

\section{References}

[1] M.J. Baldo, S. Lamansky, P.E. Burrows, M.E. Thompson, S.R. Forrest, Very high-efficiency green organic light-emitting devices based on electrophosphorescence, Appl. Phys. Lett. 75 (1999) 4-6.

[2] C. Adachi, M.C. Baldo, M.E. Thompson, S.R. Forrest, Nearly $100 \%$ internal phosphorescence efficiency in an organic light-emitting device, J. Appl. Phys. 90 (2001) 5048-5051.

[3] K.K.-W. Lo, S.P.-Y. Li, K.Y. Zhang, Development of luminescent iridium(III) polypyridine complexes as chemical and biological probes, New J. Chem. 35 (2011) 265-287.

[4] K.K.-W. Lo, M.-W. Louie, K.Y. Zhang, Design of luminescent iridium(III) and rhenium(I) polypyridine complexes as in vitro and in vivo ion, molecular and biological probes, Coord. Chem. Rev. 254 (2010) 2603-2622.

[5] Q. Zhao, C. Huang, F. Li, Phosphorescent heavy-metal complexes for bioimaging, Chem. Soc. Rev. 40 (2011) 2508-2524.

[6] Y. You, W. Nam, Photofunctional triplet excited states of cyclometalated Ir(III) complexes: beyond electroluminescence, Chem. Soc. Rev. 41 (2012) 7061-7084.

[7] R.L. Arrowsmith, S.I. Pascu, H. Smugowski, New developments in the biomedical chemistry of metal complexes: from small molecules to nanotheranostic design, Organomet. Chem. 38 (2012) 1-35. 
[8] P. Steunenberg, A. Ruggi, N.S. van den Berg, T. Buckle, J. Kuil, F.W.S. van Leeuwen, A.H. Velders, Phosphorescence imaging of living cells with amino acid-functionalized tris(2-phenylpyridine)iridium(III) complexes, Inorg. Chem. 51 (2012) 2105-2114.

[9] A. Nakagawa, Y. Hisamatsu, S. Moromizato, M. Kohno, S. Aoki, Synthesis and photochemical properties of $\mathrm{pH}$ responsive tris-cyclometalated iridium(III) complexes that contain a pyridine ring on the 2-phenylpyridine ligand, Inorg. Chem. 53 (2014) 409-422.

[10] S.W. Botchway, M. Charnley, J.W. Haycock, A.W. Parker, D.L. Rochester, J.A. Weinstein, J.A.G. Williams, Time-resolved and two-photon emission imaging microscopy of live cells with inert platinum complexes, Proc. Natl. Acad. Sci. U. S. A. 105 (2008) 16071-16076.

[11] L. Murphy, A. Congreve, L.-O. Pålsson, J.A.G. Williams, The time domain in co-stained cell imaging: time-resolved emission imaging microscopy using a protonatable luminescent iridium complex, Chem. Commun. 46 (2010) 8743-8745.

[12] P.I. Djurovich, D. Murphy, M.E. Thompson, B. Hernandez, R. Gao, P.L. Hunt, M. Selke, Cyclometalated iridium and platinum complexes as singlet oxygen photosensitizers: quantum yields, quenching rates and correlation with electronic structures, Dalton Trans. (2007) 3763-3770.

[13] A. Ruggi, F.W.B. van Leeuwen, A.H. Velders, Interaction of dioxygen with the electronic excited state of $\operatorname{Ir}(\mathrm{III})$ and $\mathrm{Ru}(\mathrm{II})$ complexes: Principles and biomedical applications, Coord. Chem. Rev. 255 (2011) 2542-2554.

[14] Y. Amao, Y. Ishikawa, I. Okura, Green luminescent iridium(III) complex immobilized in fluoropolymer film as optical oxygen-sensing material, Anal. Chim Acta. 445 (2001) 177-182.

[15] M.C. DeRosa, D.J. Hodgson, G.D. Enright, B. Dawson, C.E.B. Evans, R.J. Crutchley, Iridium luminophore complexes for unimolecular oxygen sensors, J. Am. Chem. Soc. 126 (2004) 7619-7626.

[16] L. Huynh, Z. Wang, J. Yang, V. Stoeva, A. Lough, I. Manners, M.A. Winnik, Evaluation of phosphorescent rhenium and iridium complexes in polythionylphosphazene films for oxygen sensor applications, Chem. Mater. 17 (2005) 4765-4773.

[17] S.M. Borisov, I. Klimant, Ultrabright oxygen optodes based on cyclometalated iridium(III) coumarin complexes, Anal. Chem. 79 (2007) 7501-7509.

[18] A. Zitova, J. Hynes, J. Kollar, S.M. Borisov, I. Klimant, D.B. Papkovsky, Analysis of activity and inhibition of oxygen-dependent enzymes by optical respirometry on the LightCycler system, Anal. Biochem. 397 (2010) 144-151.

[19] X.-D. Wang, O.S. Wolfbeis, Optical methods for sensing and imaging oxygen: materials, spectroscopies and applications, Chem. Soc. Rev. 43 (2014) 3666-3761.

[20] S. Zhang, M. Hosaka, T. Yoshihara, K. Negishi, Y. Iida, S. Tobita, T. Takeuchi, Phosphorescent light-emitting iridium complexes serve as a hypoxia-sensing probe for tumor 
imaging in living animals, Cancer Res. 70 (2010) 4490-4498.

[21] T. Yoshihara, Y. Yamaguchi, M. Hosaka, T. Takeuchi, S. Tobita, Ratiometric molecular sensor for monitoring oxygen levels in living cells, Angew. Chem. Int. Ed. 51 (2012) 4148-4151.

[22] T. Yoshihara, A. Kobayashi, S. Oda, M. Hosaka, T. Takeuchi, S. Tobita, Iridium complex probes for monitoring of cellular oxygen levels and imaging of hypoxic tissues, Proc. SPIE 8233 (2012) 82330A1-82330A8.

[23] T. Murase, T. Yoshihara, S. Tobita, Mitochondria-specific oxygen probe based on iridium complexes bearing triphenylphosphonium cation, Chem. Lett. 41 (2012) 262-263.

[24] S.P.-Y. Li, T.S.-M. Tang, K.S.-M. Yiu, K.K.-W. Lo, Cyclometalated iridium(III)-polyamine complexes with intense and long-lived multicolor phosphorescence: synthesis, crystal structure, photophysical behavior, cellular uptake, and transfection properties, Chem. Eur. J. 18 (2012) 13342-13354.

[25] B. Wang, Y. Liang, H. Dong, T. Tan, B. Zhan, J. Cheng, K.K.-W. Lo, Y.W. Lam, S.H. Cheng, A luminescent cyclometalated iridium(III) complex accumulates in mitochondria and induces mitochondrial shortening by conjugation to specific protein targets, ChemBioChem 13 (2012) 2729-2737.

[26] M.D. Brand, D.G. Nicholls, Assessing mitochondrial dysfunction in cells, Biochem. J. 435 (2011) 297-312.

[27] P. Ježek, L. Plecitá-Hlavatá, K. Smolková, R. Rossignol, Distinctions and similarities of cell bioenergetics and the role of mitochondria in hypoxia, cancer, and embryonic development, Int. J. Biochem. Cell Biol. 42 (2010) 604-622.

[28] J. Aragonés, P. Fraisl, M. Baes, P. Carmeliet, Oxygen sensors at the crossroad of metabolism, Cell Metab. 9 (2009) 11-22.

[29] Y. Will, J. Hynes, V.I. Ogurtsov, D.B. Papkovsky, Analysis of mitochondrial function using phosphorescent oxygen-sensitive probes, Nat. Protoc. 1 (2006) 2563-2572.

[30] E. Takahashi, K. Asano, Mitochondrial respiratory control can compensate for intracellular $\mathrm{O}_{2}$ gradients in cardiomyocytes at low $\mathrm{PO}_{2}$, Am. J. Physiol. Heart Circ. Physiol. 283 (2002) H871-H878.

[31] E. Takahashi, H. Endoh, K. Doi, Intracellular gradients of $\mathrm{O}_{2}$ supply to mitochondria in actively respiring single cardiomyocyte of rats, Am. J. Physiol. 276 (1999) H718-H724.

[32] E.G. Mik, J. Stap, M. Sinaasappel, J.F. Beek, J.A. Aten, T.G. van Leeuwen, C. Ince, Mitochondrial $\mathrm{PO}_{2}$ measured by delayed fluorescence of endogenous protoporphyrin IX, Nat. Methods 3 (2006) 939-945.

[33] E.G. Mik, T. Johannes, C.J. Zuurbier, A. Heinen, J.H.P.M. Houben-Weerts, G.M. Balestra, J. Stap, J.F. Beek, C. Ince, In vivo mitochondrial oxygen tension measured by a delayed fluorescence lifetime technique, Biophys. J. 96 (2008) 3977-3990.

[34] S.I.A. Bodmer, G.M. Balestra, F.A. Harms, T. Johannes, N.J.H. Raat, R.J. Stolker, E.G. 
Mik, Microvascular and mitochondrial $\mathrm{PO}_{2}$ simultaneously measured by oxygen-dependent delayed luminescence, J. Biophotonics 5 (2012) 140-151.

[35] X.-H. Wang, H.-S. Peng, L. Yang, F.-T. You, F. Teng, L.-L Hou, O.S. Wolfbeis, Targetable phosphorescent oxygen nanosensors for the assessment of tumor mitochondrial dysfunction by monitoring the respiratory activity, Angew. Chem. Int. Ed. 53 (2014) DOI: 10.1002/anie.201405048.

[36] R. Weissleder, A clearer vision for in vivo imaging, Nat. Biotech. 19 (2001) 316-317.

[37] K. Suzuki, A. Kobayashi, S. Kaneko, K. Takehira, T. Yoshihara, H. Ishida, S. Oishi, S. Tobita, Reevaluation of absolute luminescence quantum yields of standard solutions using a spectrometer with an integrating sphere and a back-thinned CCD detector, Phys. Chem. Chem. Phys. 11 (2009) 9850-9860.

[38] S. Batzri, E.D. Korn, Single bilayer liposomes prepared without sonication, Biochem. Biophys. Acta 298 (1973) 1015-1019.

[39] S. Lamansky, P. Djurovich, D. Murphy, F. Abdel-Razzaq, H.-E. Lee, C. Adachi, P.E. Burrows, S.R. Forrest, M.E. Thompson, Highly phosphorescent bis-cyclometalated iridium complexes: $\square$ synthesis, photophysical characterization, and use in organic light emitting diodes, J. Am. Chem. Soc. 123 (2001) 4304-4312.

[40] W.J. Finkenzeller, T. Hofbeck, M.E. Thompson, H. Yersin, Triplet state properties of the OLED emitter $\operatorname{Ir}(\mathrm{btp})_{2}$ (acac): characterization by site-selective spectroscopy and application of high magnetic fields, Inorg. Chem. 46 (2007) 5076-5083.

[41] H. Yersin, Highly Efficient OLEDs with Phosphorescent Materials, Wiley-VCH, Weinheim, Germany, 2008.

[42] A. Endo, K. Suzuki, T. Yoshihara, S. Tobita, M. Yahiro, C. Adachi, Measurement of photoluminescence efficiency of Ir(III) phenylpyridine derivatives in solution and solid-state films, Chem. Phys. Lett. 460 (2008) 155-157.

[43] N.C. Santos, M. Prieto, M.A.R.B. Castanho, Quantifying molecular partition into model systems of biomembranes: an emphasis on optical spectroscopic methods, Biochim. Biophys. Acta. 1612 (2003) 123-135.

[44] D. Marsh, Handbook of Lipid Bilayers, CRC Press, Boca Raton, FL. 1990, pp. 188-190.

[45] I. Dunphy, S.A. Vinogradov, D.F. Wilson, Oxyphor R2 and G2: phosphors for measuring oxygen by oxygen-dependent quenching of phosphorescence, Anal. Biochem. 310 (2002) 191-198.

[46] A. Heller, L.H. Fischer, O.S. Wolfbeis, A. Goepferich, Long time monitoring of the respiratory activity of isolated mitochondria, Exptl. Cell Res. 318 (2012) 1667-1672.

[47] L.F. Yousif, K.M. Stewart, S.O. Kelley, Targeting mitochondria with organelle-specific compounds: strategies and applications, ChemBioChem 10 (2009) 1939-1950.

[48] L.F. Yousif, K.M. Stewart, K.L. Horton, S.O. Kelley, Mitochondria-penetrating peptides: sequence effects and model cargo transport, ChemBioChem 10 (2009) 2081-2088. 
[49] A.T. Hoye, J.E. Davoren, P. Wipf, M.P. Fink, V.E. Kagan, Targeting mitochondria, Acc. Chem. Res. 41 (2008) 87-97.

[50] P.-K. Lee, W.H.-T. Law, H.-W. Liu, K.K.-W. Lo, Luminescent cyclometalated iridium(III) polypyridine di-2-picolylamine complexes: synthesis, photophysics, electrochemistry, cation binding, cellular internalization, and cytotoxic activity, Inorg. Chem. 50 (2011) 8570-8579.

\section{Figure captions}

Fig. 1 Chemical structures of iridium(III) complexes with a 5-amino-1, 10-phenathroline ligand used in the present study.

Fig. 2 Chemical structures of iridium(III) complexes with an acetylacetone ligand used as reference compounds.

Fig. 3 Absorption and phosphorescence spectra of (a) BTP, (b) 1a, (c) 1b, (d) 1c, (e) 2a, (f) 3a and (g) $\mathbf{4 a}$ in tetrahydrofuran (THF) at room temperature. The phosphorescence spectra were taken by the excitation at $405 \mathrm{~nm}$.

Fig. 4 (a) Phosphorescence spectral changes of $\mathbf{2 b}$ on addition of $0.003-0.1 \mathrm{mM}$ DMPC liposomes in Tris- $\mathrm{HCl}$ buffer $(\mathrm{pH} 7.0)$ at $37^{\circ} \mathrm{C}$, and (b) phosphorescence intensity changes of 2b vs. DMPC concentrations in Tris- $\mathrm{HCl}$ buffer $(\mathrm{pH} 7.0)$ at $37^{\circ} \mathrm{C}$.

Fig. 5 (a) Phosphorescence decay curves of $\mathbf{2} \mathbf{b}$, and (b) the Stern-Volmer plots of $\tau_{\mathrm{p}}^{0} / \tau_{\mathrm{p}}$ as a function of oxygen partial pressure $\left(\mathrm{pO}_{2}\right)$ in DMPC liposomes in Tris- $\mathrm{HCl}$ buffer $(\mathrm{pH}$ 7.0) at $37^{\circ} \mathrm{C}$.

Fig. 6 A. Emission images of HeLa cells incubated with BTP $(500 \mathrm{nM}), \mathbf{1 a}(500 \mathrm{nM}), \mathbf{1 b}$ $(100 \mathrm{nM}), \mathbf{1 c}(100 \mathrm{nM}), \mathbf{2 b}(100 \mathrm{nM}), \mathbf{3 b}(1 \mu \mathrm{M})$ or $\mathbf{4 b}(500 \mathrm{nM})$ for $4 \mathrm{~h}$ at $37^{\circ} \mathrm{C}$ under $2.5 \%$ $\mathrm{O}_{2}$. Exposure times of the CCD camera were $500 \mathrm{~ms}$.

B. Emission images of HeLa cells incubated with $\mathbf{1 b}(100 \mathrm{nM}), \mathbf{2 b}(100 \mathrm{nM}), \mathbf{3 b}(1 \mu \mathrm{M})$ or $4 \mathbf{b}(500 \mathrm{nM})$ for $2 \mathrm{~h}$ at $37^{\circ} \mathrm{C}$. The HeLa cells were placed in $21 \%$ and $2.5 \% \mathrm{O}_{2}$.

Custom filters used: (Ex. 400-440 nm, Em. >590 nm) for BTP, 1a, 1b, 1c and 2b; (Ex. 545-580 nm, Em. >610 nm) for $\mathbf{3 b}$ and $\mathbf{4 b}$.

Fig. 7 Emission intensities of HeLa cells incubated with (a) BTP (500 nM) and 1a (500 nM) 
(Ex. 465 nm, Em. 607 nm), (b) 1a, 1b and 1c (500 nM) (Ex. 450 nm, Em. 590 nm), (c) 2a, 2b and 2 c $(500 \mathrm{nM})($ Ex. $500 \mathrm{~nm}$, Em. $660 \mathrm{~nm})$, (d) 3a and 3b (1 $\mu \mathrm{M})($ Ex. $530 \mathrm{~nm}$, Em. $720 \mathrm{~nm})$, and (e) $4 \mathbf{a}$ and $4 \mathbf{b}(500 \mathrm{nM})($ Ex. $520 \mathrm{~nm}$, Em. $680 \mathrm{~nm})$ taken with a microplate reader. The HeLa cells were placed in $21 \%$ or $2.5 \% \mathrm{O}_{2}$.

Fig. 8 Emission images of HeLa cells upon incubation with $\mathbf{1 b}(100 \mathrm{nM}, 3.5 \mathrm{~h})$ and then with (a) Mito tracker green $(100 \mathrm{nM}, 0.5 \mathrm{~h})$ under $2.5 \% \mathrm{O}_{2}$, (b) ER tracker green $(100 \mathrm{nM}, 0.5 \mathrm{~h})$ or (c) Lyso tracker green $(100 \mathrm{nM}, 0.5 \mathrm{~h})$ under $21 \% \mathrm{O}_{2}$ at $37^{\circ} \mathrm{C}$. 
Table 1 Photophysical parameters of iridium complexes in THF at room temperature ${ }^{\text {a }}$

\begin{tabular}{|c|c|c|c|c|c|c|c|c|c|c|}
\hline Ir complex & $\lambda_{\mathrm{abs}}^{\max }(\mathrm{nm}), \varepsilon\left(\mathrm{dm}^{3} \mathrm{~mol}^{-1} \mathrm{~cm}^{-1}\right)$ & $\lambda_{\mathrm{phos}}^{\max }(\mathrm{nm})$ & $\Phi_{\mathrm{p}}$ & $\Phi_{\mathrm{p}}^{0}$ & $\tau_{\mathrm{p}}(21 \%)(\mu \mathrm{s})$ & $\tau_{\mathrm{p}}^{0}(\mu \mathrm{s})$ & $\tau_{\mathrm{p}}^{0} / \tau_{\mathrm{p}}(21 \%)$ & $\tau_{\mathrm{p}}(2.5 \%) / \tau_{\mathrm{p}}(21 \%)$ & $k_{\mathrm{p}}^{\mathrm{b}}\left(10^{5} \mathrm{~s}^{-1}\right)$ & $k_{\text {isc }}^{\prime}{ }^{\mathrm{b}}\left(10^{5} \mathrm{~s}^{-1}\right)$ \\
\hline BTP & 486,6700 & 615 & 0.005 & 0.30 & 0.11 & 5.7 & 52 & 7.4 & 0.53 & 1.2 \\
\hline $1 \mathrm{a}$ & 441,10400 & 593 & 0.009 & 0.21 & 0.29 & 8.6 & 30 & 6.7 & 0.24 & 0.92 \\
\hline $1 b$ & 440,9900 & 594 & 0.010 & 0.17 & 0.29 & 7.5 & 26 & 6.5 & 0.23 & 1.1 \\
\hline $1 \mathrm{c}$ & 440,9600 & 594 & 0.009 & 0.18 & 0.27 & 7.9 & 29 & 6.7 & 0.23 & 1.0 \\
\hline$(\mathrm{btq})_{2} \operatorname{Ir}(\mathrm{acac})$ & 543,7600 & 672 & 0.014 & 0.36 & 0.13 & 3.1 & 24 & 6.4 & 1.2 & 2.1 \\
\hline $2 \mathrm{a}$ & 505,10200 & 655 & 0.019 & 0.32 & 0.35 & 5.7 & 16 & 5.8 & 0.56 & 1.2 \\
\hline $2 b$ & 504,9600 & 656 & 0.021 & 0.30 & 0.36 & 5.6 & 16 & 5.7 & 0.54 & 1.3 \\
\hline $2 \mathrm{c}$ & 505,9200 & 657 & 0.022 & 0.31 & 0.38 & 5.8 & 15 & 5.7 & 0.53 & 1.2 \\
\hline$(\mathrm{ttph})_{2} \operatorname{Ir}(\mathrm{acac})$ & 516,11400 & 693 & 0.026 & 0.34 & 0.23 & 3.1 & 13 & 5.4 & 1.1 & 2.1 \\
\hline $3 a$ & 516,13400 & 686 & 0.017 & 0.24 & 0.44 & 6.2 & 14 & 5.5 & 0.39 & 1.2 \\
\hline $3 b$ & 515,13300 & 688 & 0.017 & 0.23 & 0.48 & 6.0 & 13 & 5.3 & 0.38 & 1.3 \\
\hline$(\mathrm{btph})_{2} \operatorname{Ir}(\mathrm{acac})$ & 529,13500 & 718 & 0.036 & 0.28 & 0.24 & 1.9 & 7.9 & 4.3 & 1.5 & 3.8 \\
\hline $4 a$ & 532,10300 & 710 & 0.024 & 0.14 & 0.39 & 2.3 & 5.9 & 3.7 & 0.61 & 3.7 \\
\hline $4 b$ & 533,10800 & 711 & 0.025 & 0.15 & 0.40 & 2.3 & 5.8 & 3.7 & 0.65 & 3.7 \\
\hline
\end{tabular}

${ }^{\mathrm{a}}$ The absorbance of each iridium complex was adjusted to $0.1-0.2$ at the excitation wavelength (405 nm), which corresponds to the concentration of 10 - 20 $\mu \mathrm{M}$ except for BTP (about $50 \mu \mathrm{M}){ }^{\mathrm{b}}$ Calculated from $k_{\mathrm{p}}=\Phi_{\mathrm{p}}^{0} / \tau_{\mathrm{p}}^{0}$ and $k_{\mathrm{isc}}^{\prime}=\left(1-\Phi_{\mathrm{p}}^{0}\right) / \tau_{\mathrm{p}}^{0}$ by assuming that $\Phi_{\mathrm{isc}}$ equals unity. 
Table 2. Phosphorescence lifetimes $\left(\tau_{1}\right.$ and $\left.\tau_{2}\right)$ and the average lifetime $\left(\left\langle\tau_{\mathrm{p}}\right\rangle\right)$ of $\mathbf{2} \mathbf{b}$ in HSA in Tris- $\mathrm{HCl}$ buffer at $37{ }^{\circ} \mathrm{C}$ as a function of oxygen partial pressure $\left(p \mathrm{O}_{2}\right)$.

\begin{tabular}{ccccc}
\hline $\mathrm{O}_{2}(\mathrm{mmHg})$ & $\tau_{1}(\mu \mathrm{s})$ & $\tau_{2}(\mu \mathrm{s})$ & $<\tau_{\mathrm{p}}>(\mu \mathrm{s})$ & $\chi^{2}$ \\
\hline 160 & $2.79(0.64)^{\mathrm{a}}$ & $4.58(0.36)$ & 3.65 & 1.05 \\
114 & $2.83(0.56)$ & $4.87(0.44)$ & 4.00 & 0.953 \\
76 & $3.15(0.40)$ & $5.16(0.60)$ & 4.57 & 0.914 \\
38 & $4.53(0.75)$ & $6.81(0.25)$ & 5.30 & 0.973 \\
0 & $3.07(0.35)$ & $6.08(0.65)$ & 5.44 & 0.930 \\
\hline
\end{tabular}

${ }^{\mathrm{a}}$ In parentheses, amplitude ratios are shown. 
Table $3 \mathrm{IC}_{50}$ values of each iridium complex toward HeLa cells.

\begin{tabular}{cc}
\hline Iridium complex & $\mathrm{IC}_{50}(\mu \mathrm{M})$ \\
\hline $1 \mathrm{a}$ & 4.0 \\
$1 \mathrm{~b}$ & 0.55 \\
$1 \mathrm{c}$ & 0.34 \\
\hline $2 \mathrm{a}$ & 5.1 \\
$2 \mathrm{~b}$ & 0.59 \\
\hline $2 \mathrm{c}$ & 0.32 \\
\hline $3 \mathrm{a}$ & 3.7 \\
\hline $3 \mathrm{~b}$ & 1.8 \\
\hline $4 \mathrm{a}$ & 3.5 \\
$4 \mathrm{~b}$ & 1.2 \\
\hline
\end{tabular}



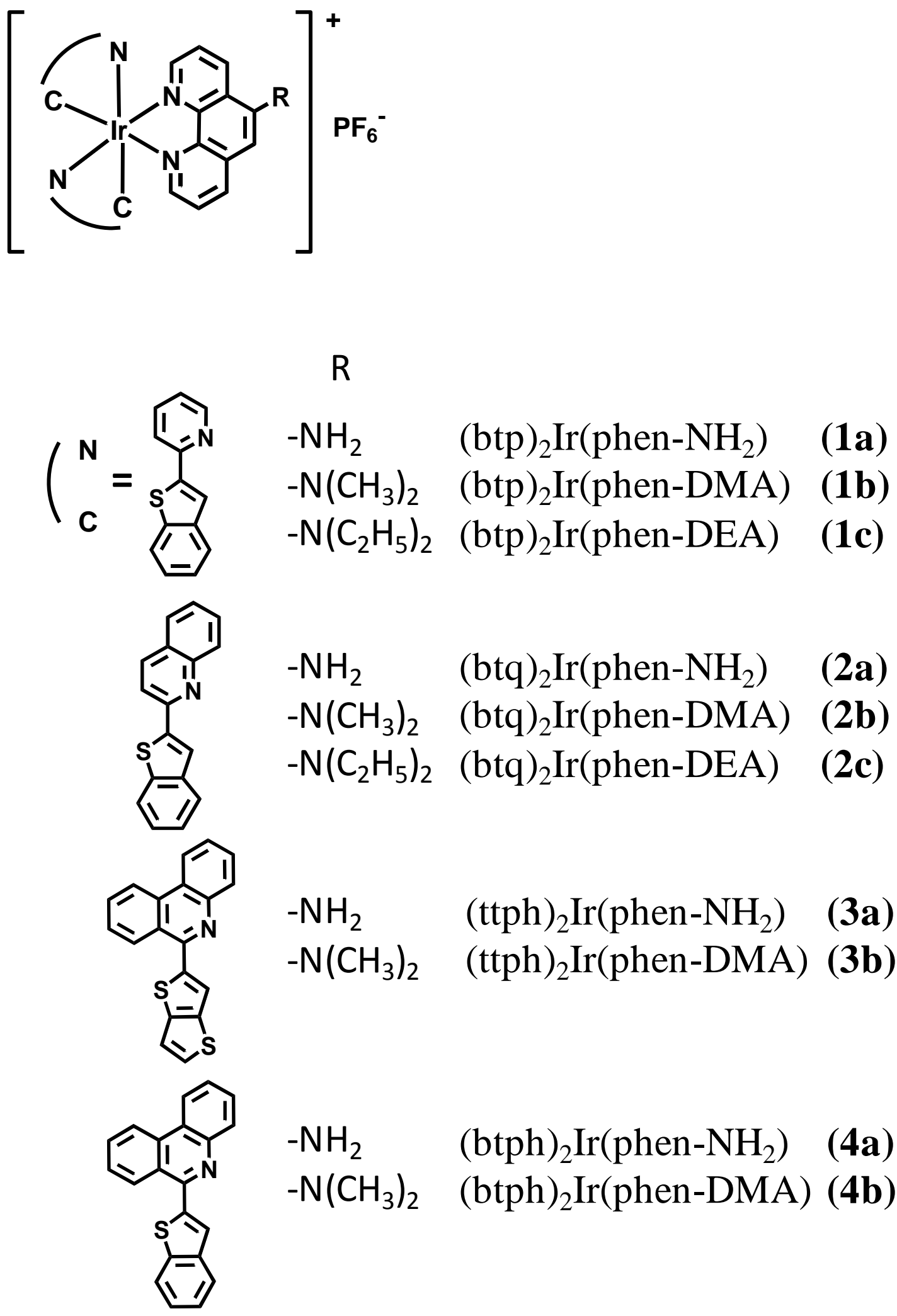

Figure 1 

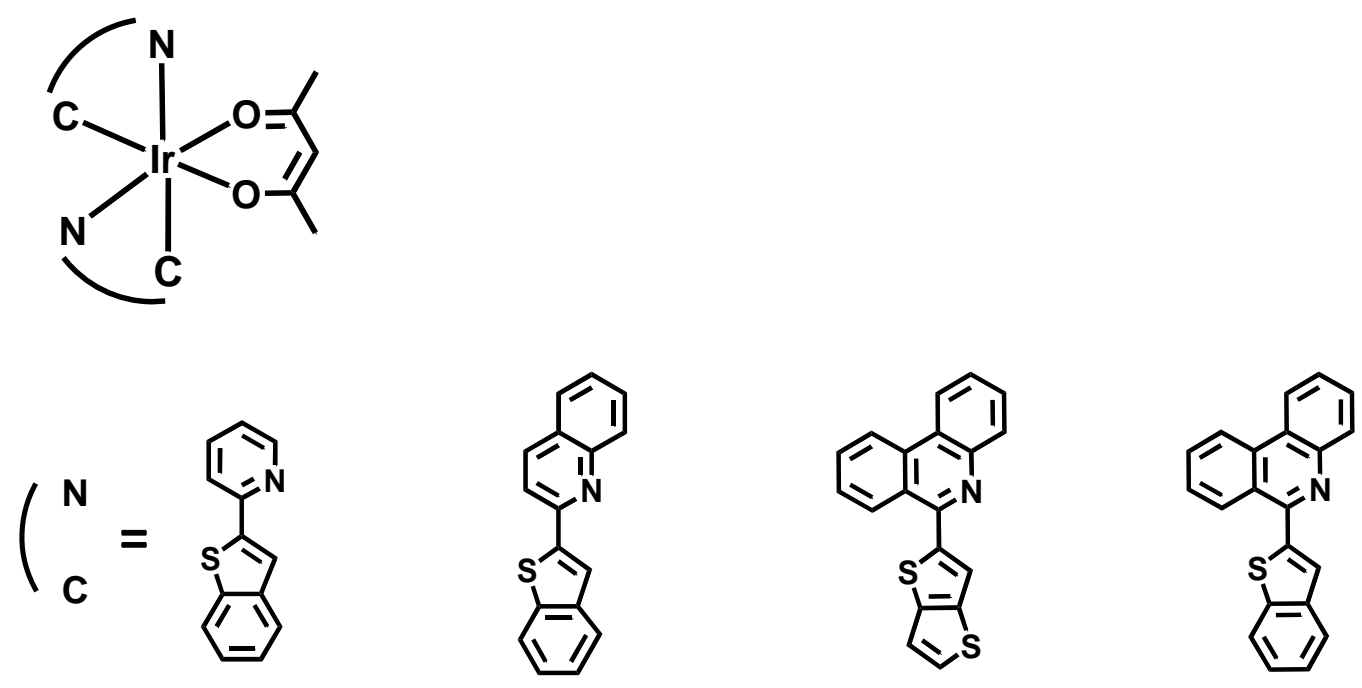

(btp) $)_{2} \operatorname{Ir}($ acac $) \quad(\text { btq })_{2} \operatorname{Ir}($ acac $) \quad(\operatorname{ttph})_{2} \operatorname{Ir}($ acac $) \quad(\text { btph })_{2} \operatorname{Ir}($ acac $)$ (BTP)

Figure 2 


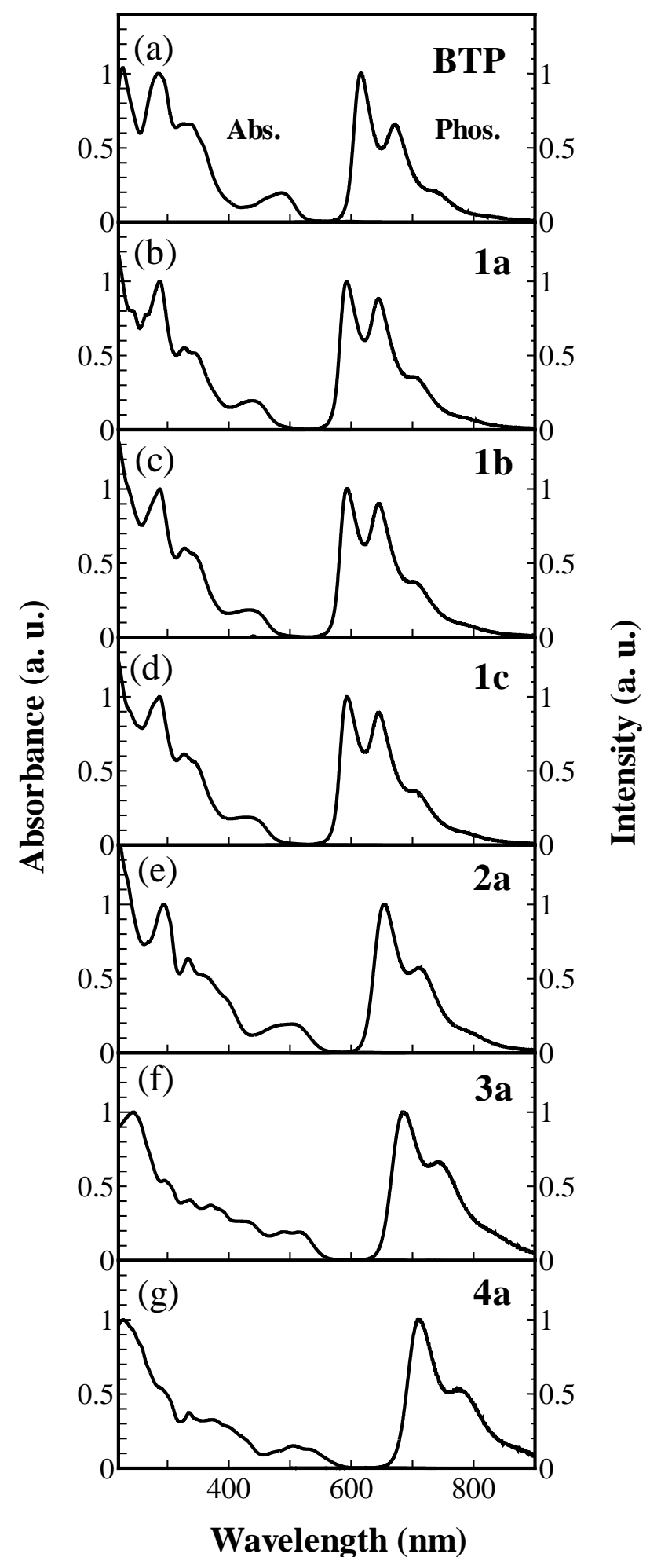

Figure 3 
(a)

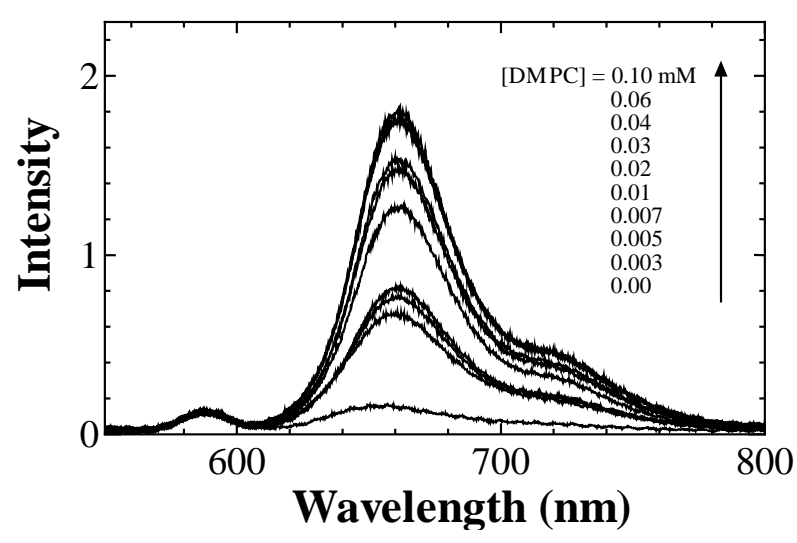

(b)

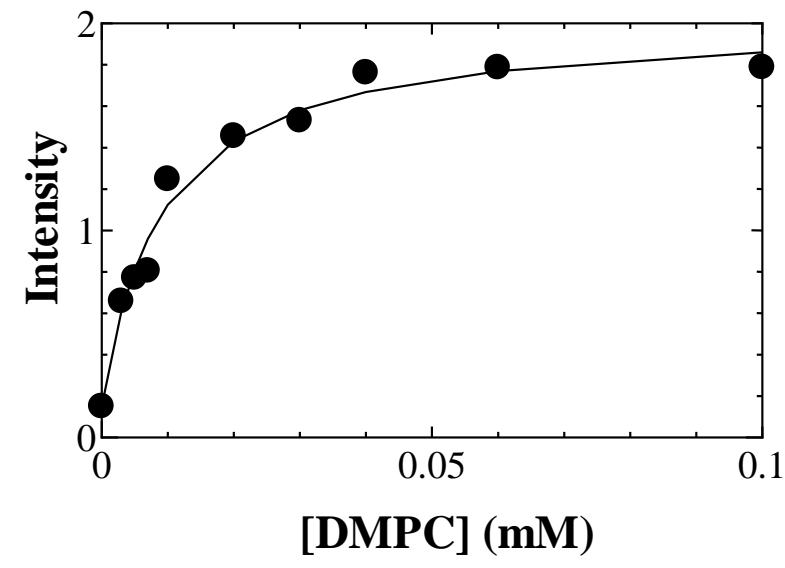

Figure 4 
(a)

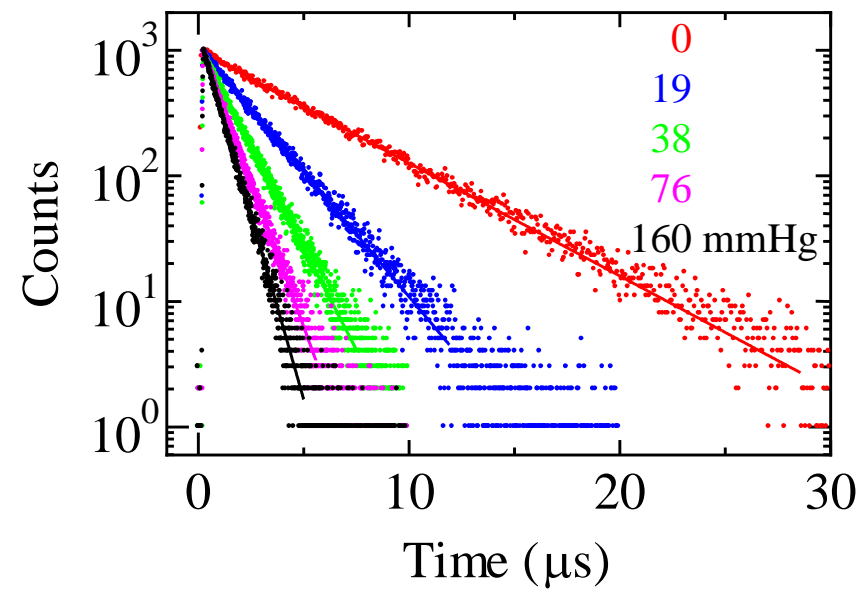

(b)

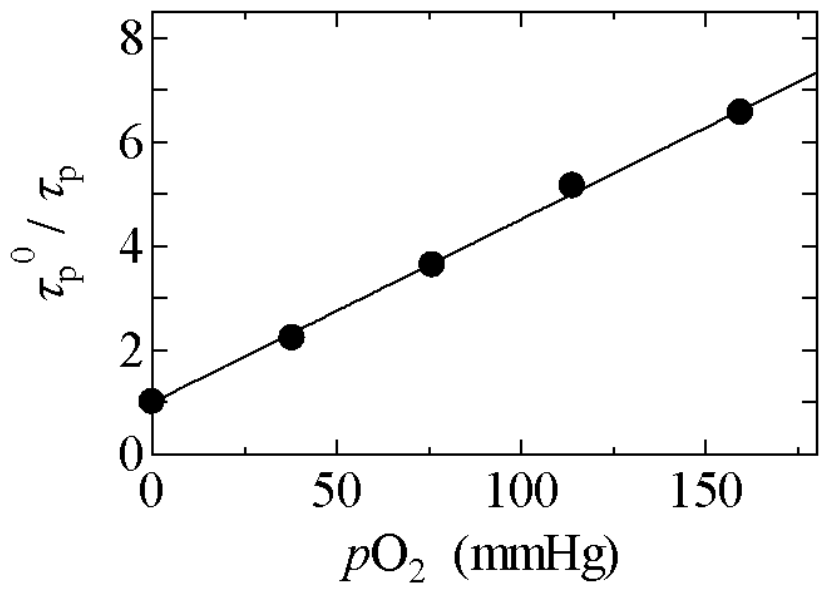

Figure 5 
A
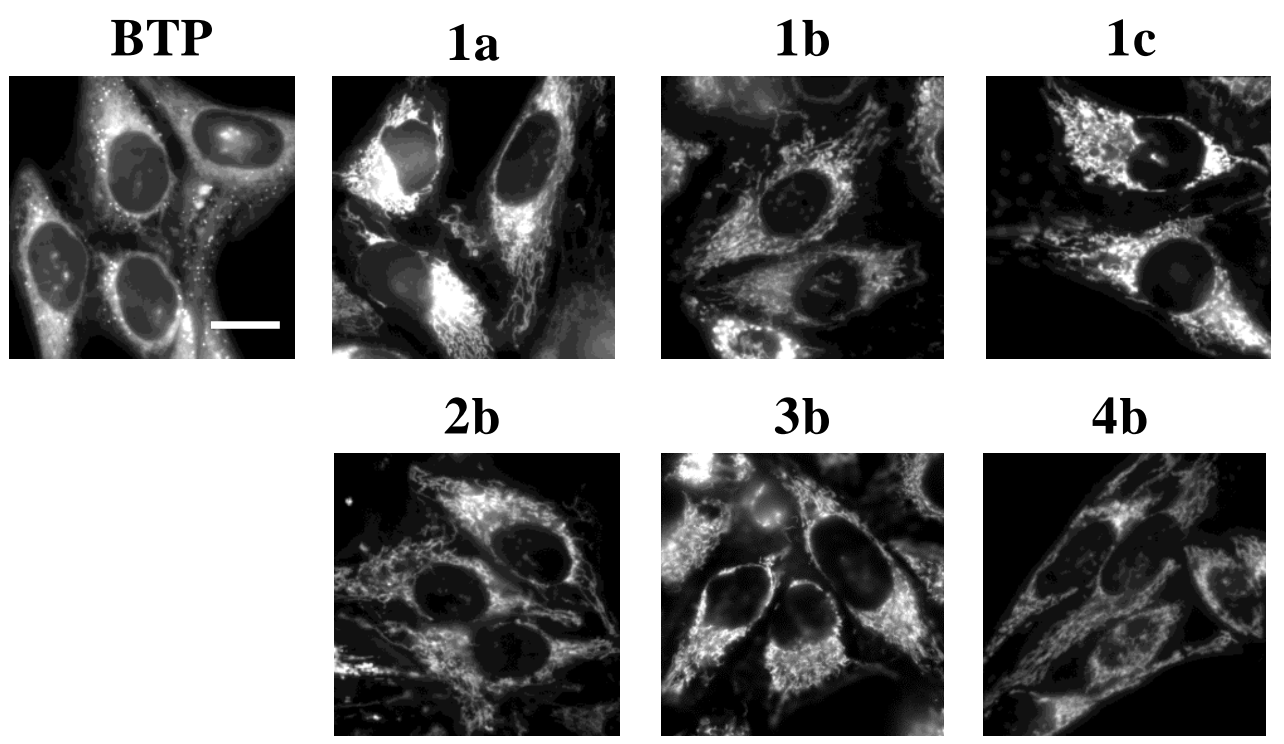

B
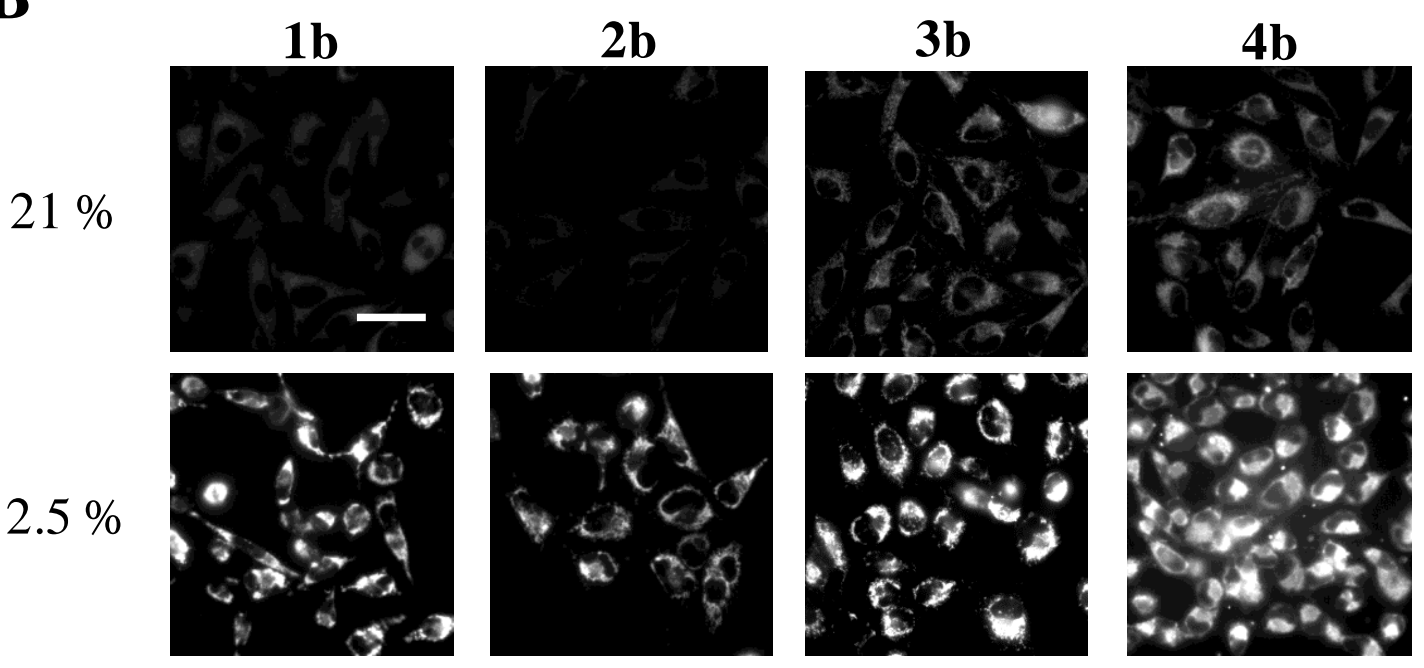

Figure 6 


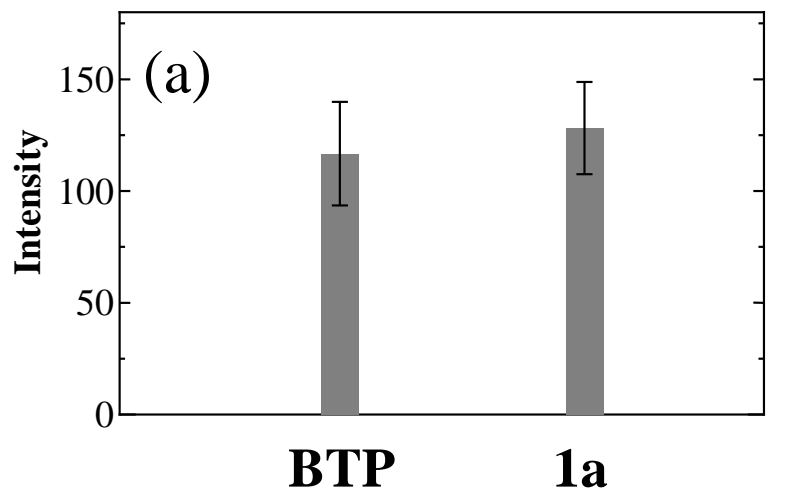

$\square 21 \% \mathrm{O}_{2}$
$2.5 \% \mathrm{O}_{2}$
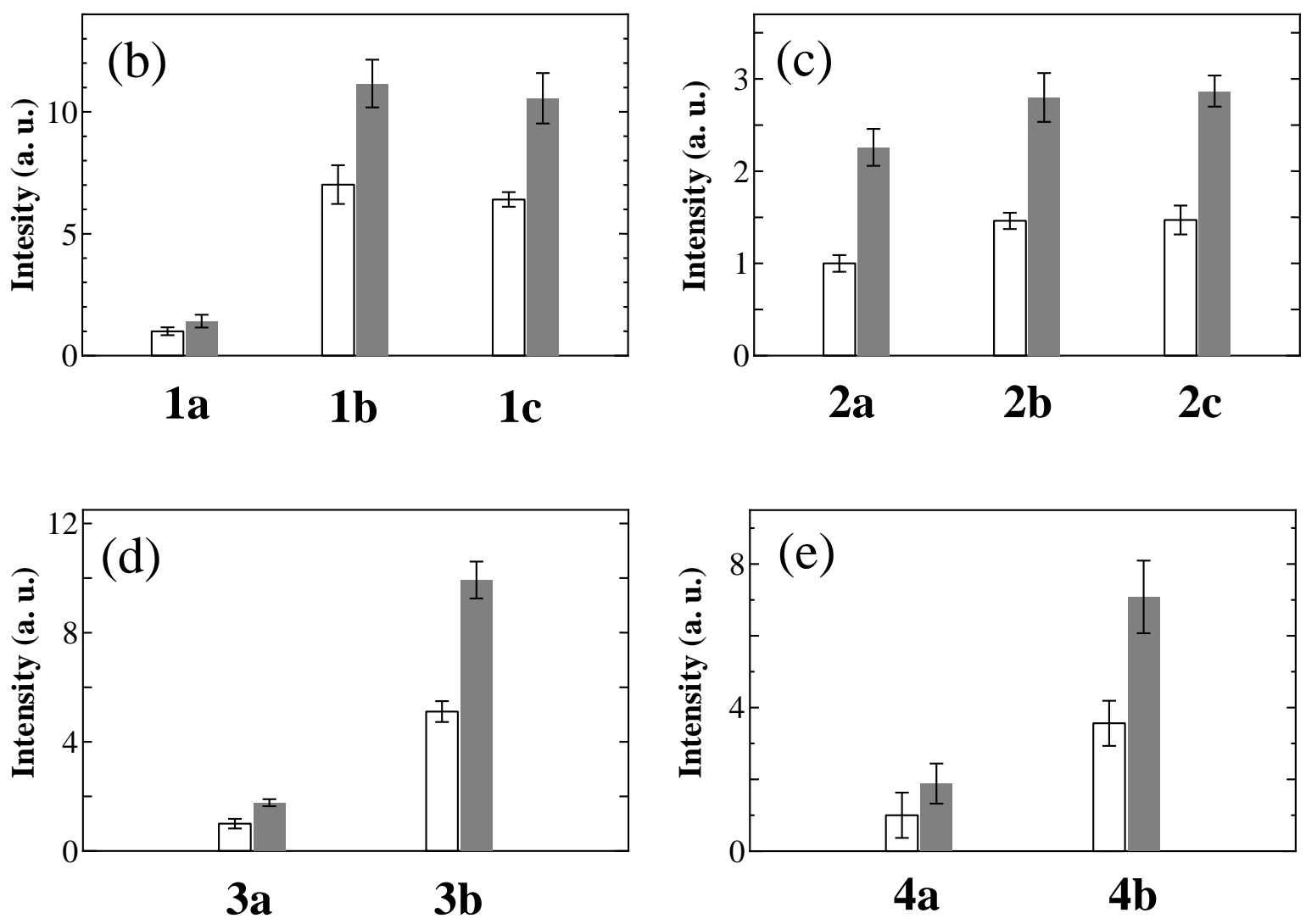

Figure 7 


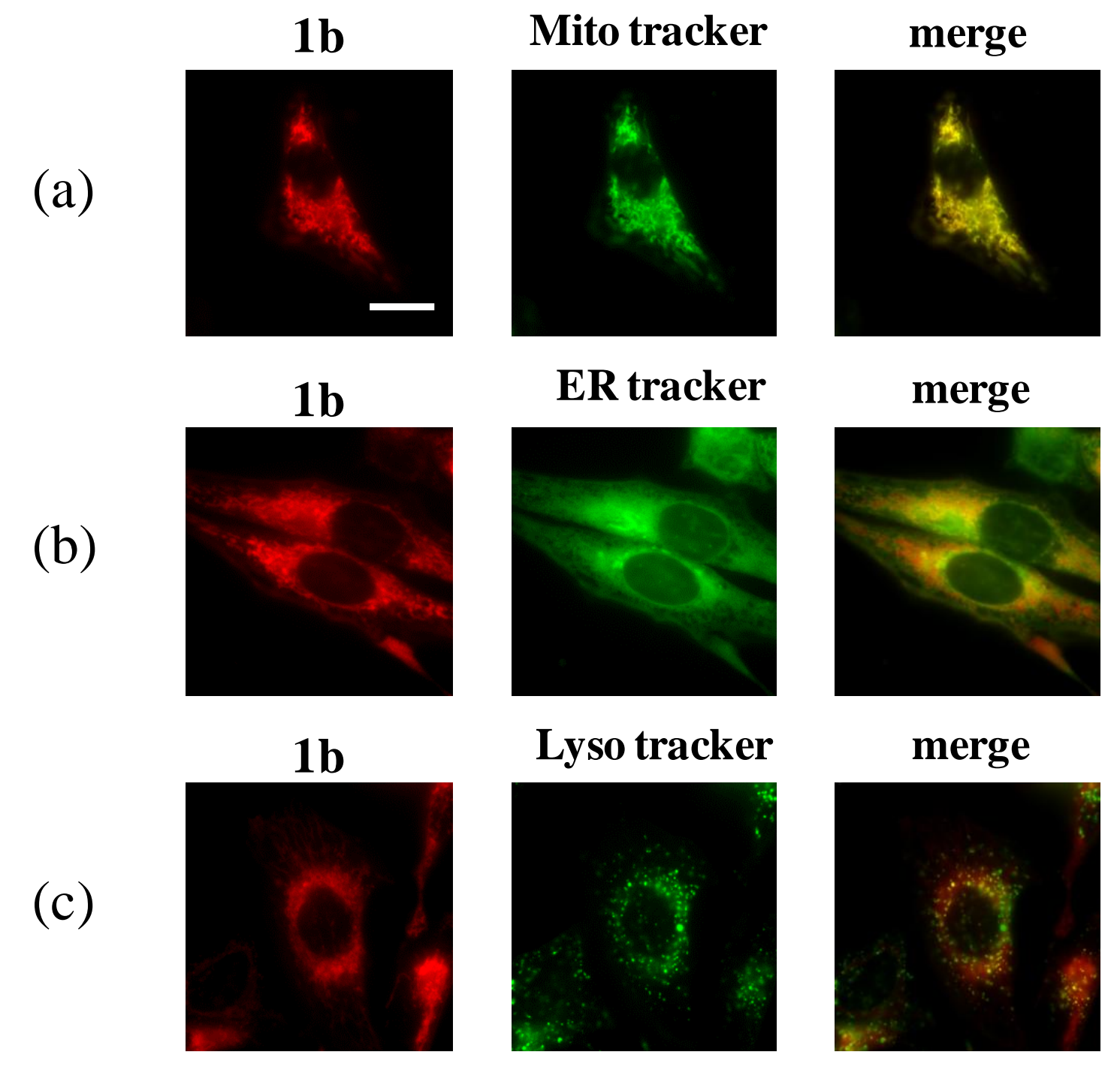

Figure 8 


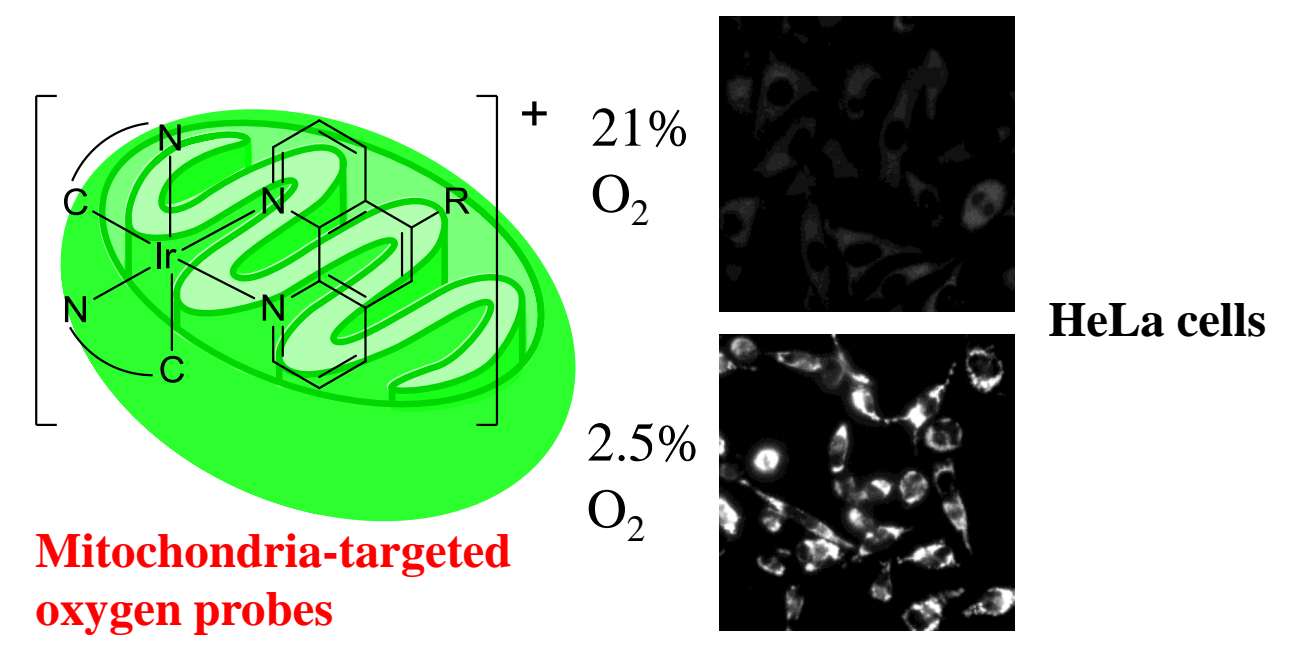

Mitochondria-targeted oxygen probes 